\title{
Plankton Studies in Relation to the Western Mackerel Fishery.
}

\author{
By \\ G. E. Bullen.
}

With Six Charts (Plates XVIII-XXIII), two Figures in the Text and Tables I-V.

\section{METHODS.}

THE researches here described extended for intermittent periods over the years 1906 and 1907 , and were primarily intended to embrace inquiry into the food problem of Pilchard, Herring, and Mackerel frequenting the western part of the English Channel. The observations now recorded form, therefore, a part of a wider series.

Most of the information referring to the condition of the fishery throughout the spring season of the two years was collected at Newlyn and Plymouth, by systematic inquiry amongst the fishermen. Other information was derived from the market reports of the Fish Trades Gazette and other journals, and from Mr. Mathias Dunn of Newlyn, who kept the fishery constantly under observation.

The samples of plankton and stomach material were obtained from various sources. Some were taken by myself at sea from fishing-boats or from the Oithona, others by fishermen; whilst a good deal of the stomach material was got from systematic collections made at Plymouth and Newlyn from catches landed at those ports. In addition to the plankton samples mentioned above, certain samples taken at the western stations during the international cruises were also examined and the results utilized.

The plankton was collected for the most part by a compound townet embodying in its construction Swiss bolting silk of two sizes of mesh, viz. (a) 18 holes per $1 \mathrm{~cm}$., the average length of a hole being $.056 \mathrm{~cm}$. and the average breadth being $.036 \mathrm{~cm}$., and (b) 70 holes per $1 \mathrm{~cm}$. The surface hauls were usually made for ten minutes. The contents of the net were filtered through a net-bag constructed of the fine silk mentioned above, and the product preserved in $5 \%$ formalin. 
In certain cases the samples were collected by two separate nets, of coarse and fine mesh respectively.

As this paper does not deal with plankton other than in its direct bearing upon mackerel food, it has been considered desirable, for purposes of easy reference, to include the surface hauls with those taken from bottom to surface (oblique) under one column for each position noted on the Plankton Tables (Tables I, II). In thus combining the analyses of the surface and oblique hauls, it may be mentioned that the comparative signs (which are those adopted in the International Plankton Investigations) placed against the Phytoplankton species are those derived from the analysis of the surface haul, whilst for Zooplankton the higher of the two values recorded for the surface and oblique hauls is used.

In the determination of the plankton samples, a general examination was first made under magnification $\times 48$ and $\times 160$ in a shallow trough. The phytoplankton was subsequently examined under coverslip with higher powers, $\times 520$ to $\times 824$, etc.

In the greater number of cases six stomachs were collected from every catch and preserved in $10 \%$ formalin. The contents of each were subsequently washed out into Petrie dishes and examined in a similar manner to that described for plankton. The whole of the sample, unless very bulky, was examined. Other modifications of detail with reference to stomach samples are explained under a later heading, page 273 .

My thanks are largely due to Dr. E. J. Allen, who has materially assisted me throughout the investigation and in the preparation of this paper; also to Mr. Mathias Dunn, for much valuable help in the collection of observations and material. I here also desire to express my thanks to Mr. Howard Dunn, Mr. D. J. Mathews, Dr. L. H. Gough, and Mr. W. Bygrave, for assistance in the collection or identification of material, and to Mr. A. E. Hefford for help in the preparation of this paper.

\section{THE WESTERN SPRING MACKEREL FISHERY.}

THE factors, which influence the inshore migration of mackerel in greater or less abundance, have long been the subject of inquiry. That the purpose of spawning is the primary object of such migration has been admitted, but it still remains to show reasons for the greater or less extent of this migration, which from a commercial standpoint, under the present system of drift fishing, is equivalent to a good, bad, or indifferent season. Many previous authors have shown that 
plankton forms the main food of mackerel during the shoaling season, and the examination of more than four hundred stomachs of mackerel taken in the British Channel and extreme western part of the English Channel, during the present investigations (1906-7), has shown agreement with this result. As suggested by several previous authors on the subject, it appears possible that from a study of this food some light may be thrown upon the factors which govern the fluctuations in the mackerel fishery during the spring shoaling season. The object of this paper, therefore, is to show, from the information and observations at our disposal, whether there is a demonstrable correlation between the distribution of plankton or mackerel food, and the extent of migration. It has already been stated that over four hundred stomachs have been examined during the present researches. These were taken in 1906-7 from fish caught in the Bristol Channel and in the English Channel from Plymouth to west of Scilly, during the three months which constitute the more important part of the spring fishery, viz. April, May, and June. The result of the analyses of these stomachs will be found in the Plankton and Food Tables which are appended. From an examination of these tables it will be seen that on no occasion has an instance occurred of material, other than plankton, being observed in the stomachs of fish caught during the shoaling season in the extreme western part of the area under consideration. In the eastern part, however (see Table V), it will be seen that the plankton forming the principal food was gradually supplemented, as the season advanced, with young fish and adult Crystallogobius nilsoni. .

From information derived from the weekly market reports published in the Fish Trades Gazette, and from statements made to me by local fishermen at Plymouth and Newlyn, it would appear that, although drift fishing had been carried on in the Bristol Channel and elsewhere since the beginning of February until April in 1906 and 1907, the catches made were irregular and comparatively small. Fishermen and others agreed in stating that this was due to the fact, that there appeared to be no regular shoaling at the surface during these three months.

That mackerel did occur, however, in the inshore waters at this time at the surface is evinced by the fact that fair catches of hook fish were made constantly during the early months of the two years, as shown by the market reports, and by the writer's personal observations.

Fishermen seem to be agreed that shoaling mackerel will not take a bait: and a consideration of the above facts tends to suggest that in 
these early spring months mackerel may be present at the surface but are disseminated over a wide area. A careful comparison of the plankton results for the February cruises, shown in the Bulletins Conseil International pour l'exploration de la Mer, shows that, at the western midChannel and Bristol Channel stations (E. 5 and E. 6, the only two falling within the fishing area), plankton generally has reached a minimum in comparison with other quarterly results. It is desirable at this point to state that, for the purpose of comparison in this and other cases, an arbitrary numerical value was substituted for the comparative signs employed in the tables, viz. $+=10, c=100, c c=500$, the signs " $\mathrm{r}$ " and "rr" being disregarded. In the present instance comparison. was made for all the years since the commencement of the international investigations, and this condition appeared to be invariably the same. This point is furtlier supported by certain observations taken during the present investigations (Nos. 2, 3, 4, 5, 6, Table I).

These two main facts considered together cannot, however, be offered as sufficient evidence that mackerel do not shoal closely at the surface until there is a sufficiency of plankton to form food for their support without much individual effort, especially in view of the fact that mackerel are known to be shoaling densely at the bottom off Start Point in the early part of the year, and, as far as our present observations extend, are feeding there upon plankton. Possibly, however, it may be suggested reservedly that a lack of plankton may exercise a retarding influence upon the shoaling of fish already at the surface, which are disseminated over a wide area, of the presence of which evidence has already been given. Further, attention has already been drawn to the fact that in the Plymouth to Lizard area in 1907 larger food material was observed, in gradually increasing quantity as the season advanced, from the end of April onwards. Throughout July, 1907, from the writer's personal observations, the plankton in the Plymouth area was observed to decrease very materially in quantity. In the previous month, the tow-nettings brought to the Laboratory at Plymouth from within and outside the Sound for the use of students, and for the Plymouth plankton records taken weekly, were composed mainly of Temora longicornis in extreme abundance. During the first few days of July, within the first week, the Copepod in question, from being extremely abundant, rapidly disappeared from the tow-nettings, leaving the samples almost clear, for the time being, of animal life. No plankton observations were obtained from the western area during July, 1907; but, confining our attention to the Plymouth to Lizard area, it appeared that from all reports the shoals broke up at about this time and the hand-lining season commenced. It may, therefore, be sug- 
gested, that, until individual effort on the part of the fish to secure food becomes necessary, the mackerel remain in shoals.

These results tend to support the theory that mackerel feed upon plankton only when shoaling.

Owing to a certain general similarity in the samples examined, it was found possible to tabulate the results of the analyses of the stomach material. These are given in the Plankton and Food Tables (III, IV, and V) which are appended. From nearly every position noted therein the contents of six stomachs were examined, and, by a system of adopting the highest comparative symbol placed against the different species throughout the series, a single sample was formed. This, in certain instances, is shown for comparison with a plankton sample collected on the same position as that from which the fish themselves were derived.

It has proved convenient to arrange the results in three separate tables, viz. Western Area, 1906; Western Area, 1907; and Plymouth to Lizard Area, 1907. Lack of observation in this latter area in the earlier year has prevented the formation of a separate table for 1906 .

It will be seen that only those principal species, which occurred more or less regularly in the stomach contents, have been included in the tables. These comprise seven species of Copepods, viz. Acartia clausi, Calanus finmarchicus, Centropages typicus, Metridia lucens, Paracalanus parvus, Pseudocalanus elongatus, and Temora longicornis. An examination of the tables will show that of these species Calanus finmarchicus, Pseudocalanus elongatus, and Temora longicornis are the most important. The other species, although persistently occurring in stomach contents, are hardly of sufficient importance for purposes of comparison.

In addition to the Copepods there are included in the tables, Zoeae, Sagitta bipunctata and Oikopleura dioica. These species, together with the Copepods, constitute the principal forms of zooplankton observed in the stomach contents.

For the Plymouth to Lizard area it was found necessary to include young fish, or Crystallogobius. The last item for consideration, which is noted on every table as "Phytoplankton, chiefly Phaeocystis globosa," refers to the material largely found in mackerel stomachs in the early part of the season. This, upon examination, in many instances proved to be diatom detritus, consisting of the shells, spines, chromatophores, and the jelly-like substance associated with them, forming in a majority of cases a glairy mass of a dark green tint.* Associated with this material in a number of instances was a certain quantity of Phaeocystis

* For the exact diagnosis of the nature of this material the writer is indebted to Mr. A. J. Mason-Jones. 
globosa, the exact proportion of which it was found impossible to gauge. In certain samples, however, owing to the absence of diatoms and other protophyta (Samples 68, 69, 93, 94, Tables III, IV), it was found possible to estimate the amount of Phacocystis with more probability.

It may be mentioned that Cunningham, ${ }^{*}$ in describing the early spring food of mackerel, remarks, "In some [stomachs] there occurred a quantity of the green slimy vegetable matter, which was then abundant in the sea."

During the examination of certain series of stomachs, instances have occurred where the contained food was deposited in layers (Samples Nos. 94, 120, 121, 123, 124, etc., Tables IV, V). Farran (Report on Sea and Inland Fisheries, Ireland, 1901, Part II, p. 122) records the same thing, and $\mathrm{Mr}$. W. M. Tattersall informed the writer that he has frequently observed a similar condition in mackerel from the west of Ireland. Such a state of the stomach contents is specially obvious where the Pteropod Limacina retroversa (Flem.) occurs together with one or more species of Copepods, the dark colour of the former contrasting sharply with the bright orange tint of the latter. It has often been suggested that certain plankton organisms occur in shoals of varying extent. Now it is interesting to note in this connection, that many fishermen think that shoaling mackerel, when feeding, scarcely move at all, beyond maintaining their position against the current. The theory of the fish feeding, therefore, first in one shoal of plankton organism and then in another as they pass, may be suggested as an explanation of this phenomenon. The fact might also be due to the fish swimming first in one and then in another layer of water.

By an examination of the Food and Plankton Tables it will be seen that the plankton organisms occurring in the stomach contents are common also to tow-nettings taken on the same position. In a majority of cases also, the relative proportions of individual species are similar in both, or nearly so. Occasionally differences occur. But in the examination of the large mass of material which is generally found in a mackerel stomach when plankton is abundant, it is often difficult to decide the comparative proportion of one species to another. This fact, together with that of the method of treatment already explained (see p. 273), will account for the differences which are occasionally shown between the analyses of stomach contents and those of plankton samples from the same locality.

Although, however, certain species occurring in the tow-nettings are

* Marketable Marine Fishes, p. 313. 
observed in the stomach material of fish from the same position, an exhaustive examination of a fair number of stomach samples has failed to show the presence of the same variety of organisms in the stomach, as occur in the tow-nettings taken on the same positions as the mackerel. Possibly this fact may be offered as additional evidence in support of the food-layer theory already mentioned.

In the early part of April, 1906, as in the two preceding months, an unprofitable fishery had been carried on in the Bristol Channel by the greater number of the steam drifters. From fishermen's reports this condition had, it appeared, continued since the commencement of the season without a single period of improved fishing. On the 20th of April, however, some good shoals were struck to the south-west of the Wolf by the sailing fleet. The greater number of the steam drifters at once left the Bristol Channel and commenced fishing in a semicircle to the south and south-west of Scilly. The result was that moderate but regular catches of ten thousand down were landed from this area, the fishing although light being general. The stomach contents of samples of these fish did not differ very materially from those of Bristol Channel fish (see Samples Nos. 66, 67, Table III).

A line of plankton samples was taken at this time from Plymouth to the fishing area south-west of the Wolf, the chief aim being the determination of the relative quantities of zooplankton and phytoplankton* present on the fishing area and adjacent waters. The analyses of the tow-nettings taken on 23rd and 24th April during this cruise (see Samples Nos. 11-20, Table I) are interesting when viewed in relation to the distribution of shoaling mackerel at the time. Briefly summarized, it appeared that from Plymouth to the Lizard phytoplankton in every example was in excess of zooplankton (Samples Nos. 11, 12, 13, and 20, Table I). In the single position in Mount's Bay where tow-nettings were taken this was also the case (Sample No. 19, Table I), whereas in samples taken, on the approach to the fishing area and actually on the ground (Samples Nos. 14-17), there was a rapid decrease in phytoplankton, leading to a reverse of the former condition, i.e. to an excess of zooplankton over phytoplankton. It may be mentioned that the excess of phytoplankton over zooplankton was largely, though not entirely, due to the presence in the samples of large quantities of Phaeocystis globosa, Scherffel.

* Throughout this paper the word "phytoplankton" must be understood as referring to the larger organisms, such as are recorded in the plankton tables of the International Bulletin. No investigations have been made on the minute plankton organisms which Lohmann has included under the term " microplankton." 
From a comparison of the tables it will be seen that the reverse condition was not brought about entirely by the decrease of the Phaeocystis, but also by the increasing number of the Copepods in the samples.

During this cruise, through lack of time, only one position could be worked in the Bristol Channel (Sample No. 18, Table I), which showed phytoplankton in excess of zooplankton. The same condition was observed in a sample taken at Sevenstones five days later. The positions of the stations on this cruise and the general distribution of samples taken during April, 1906, can be readily understood on reference to the Distribution of Species Chart No. 1.

Throughout the early part of April, 1907, from the fishermen's reports it appeared that fairly regular catches had been landed from the Bristol Channel south-west of the Wolf, and also from twenty to thirty miles S.W. of the Lizard. Many fishermen declared, however, that the water lying within a ten-mile or wider limit from the coast from off Plymouth to Land's End, was in that particular condition which they termed "stinking," and of a most unsuitable condition for the presence of mackerel.*

In order to obtain observations in this affected area, and also to trace the varying proportions of zooplankton and phytoplankton on the fishing ground, a cruise was taken from Plymouth to ten miles S.W. of the Wolf, and from thence to twenty miles north of the Longships, somewhat earlier than in 1906, viz. April 16th, 17th. The analyses of the tow-nettings taken (see Samples Nos. 41-8, Table II) show a somewhat similar condition to that observed in 1906, with certain important exceptions. The main differences lie in the excess of phytoplankton extending farther westward past the Lizard (see Samples Nos. 41-5, Table II). This condition was largely due to Phacocystis; zooplankton occurring in excess of phytoplankton only in the sample taken farthest west, viz. ten miles S.W. of the Wolf (No. 48, Table II). A more important feature, however, appears to lie in the conditions observed in the Bristol Channel samples (Nos. 46, 47, Table II), where zooplankton occurred decidedly in excess of phytoplankton. For a synoptic view of these observations, showing the positions of stations, the reader is referred to Distribution of Species Chart No. IV.

Now in drawing a comparison between the condition exhibited by the plankton and that by the fishery in April 1906 and 1907, it will be seen that in the former year, phytoplankton appearing in excess of zooplankton in the Bristol Channel, the fishery there was unprofitable; whereas the reverse obtaining S.W. of the Wolf, fair catches were

\footnotetext{
* See note on "Stinking Water," p. 289.
} 
made there. In 1907, on the other hand, zooplankton was in excess of phytoplankton both in the Bristol Channel and also to the S.W. of the Wolf, in both of which areas good fishing was obtained. In considering these observations further, it is interesting to find that the most profitable fishing grounds lay outside the area in which phytoplankton predominated, which suggests that mackerel during the shoaling season prefer an animal to a vegetable diet, and may be met with in quantity where such food is abundant.

Further consideration of the Distribution of Species Charts IV to VI shows wider eastward distribution of shoaling mackerel as the season proceeded in 1907.

An examination of the Plankton Tables Nos. I and II shows, moreover, that throughout the season, during 1906, phytoplankton was always in evidence, whereas in 1907 it entirely disappeared from the beginning of May onward until the close of the season. The official statistics of monthly landings, published by the Board of Agriculture and Fisheries show that the fishery in 1906 was phenomenally bad, whereas that of 1907 was very good.

From these two facts it may be suggested that excess of phytoplankton in inshore waters retards or rather limits the eastern migration of the shoals first appearing west of Scilly.

An examination of the official statistics of mackerel landings serves to show that, in the month of May, the quantity of mackerel caught has reached a maximum for the four months forming the more important part of the spring fishery. The following table shows the figures from 1901-7 inclusive. The figures given represent the landings on the south and west coasts of England and Wales, which are significant for the western fishery, since comparatively few mackerel are taken elsewhere during the months dealt with.

Table showing Official Returns of Mackerel landed on the south and west coasts of England and Wales, from March to June inclusive, in the years 1901-7.

TOTAL IN HUNDREDWEIGHTS.

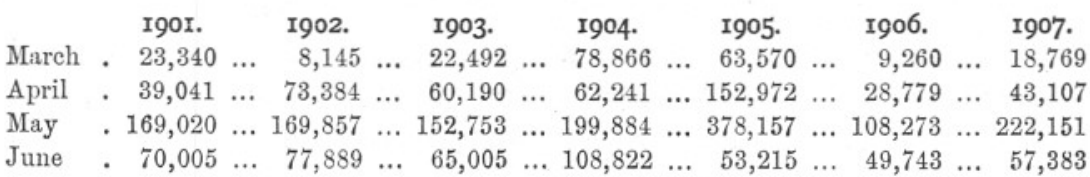

As these figures are taken over a fair number of years it may be assumed that during May, under normal conditions, the fishery is at its height. In May also the maximum number of boats are generally 
fishing, and during the latter part of the period considered there is no reason to suppose that the number of boats has greatly altered. The fluctuation, as shown by the official figures, in consideration of the usual fair-weather conditions during this month, is less liable to be influenced by causes other than the greater or less extent of migration.

On reference to the above table it will be seen that in May, 1906, the landings touched a minimum for the seven years; whereas, although the figures in no way compare with those of 1905, the May landings for 1907 are suggestive of a good season. The good May fishing of 1907 as opposed to the bad of 1906 forms a useful comparison when we come to consider plankton conditions of the same period in these two years.

From an examination of the daily market reports published in the Fish Trades Gazette, it would appear that in 1906 the fishery was gradually improving throughout May until the last week, when, after a short period of improved conditions, it began rapidly to decline, and remained depressed until the end of the season.

In 1907, from information derived from the same source, and from observations taken at Newlyn by Mr. W. Bygrave, it appeared that heavy landings of mackerel took place during the first and second weeks in May. The market was several times glutted; and there is every reason to suppose that, had not a short spell of bad weather intervened, in which the men temporarily lost sight of the shoals, the landings would have been considerably greater than they appear to be from the official statistics. However, despite the unfavourable comparison between the figures for May, 1905, and those of 1907, from all accounts there is every reason to consider the latter year to have been an excellent season.

In reviewing the plankton conditions generally, it should first be pointed out that throughout May, 1906, phytoplankton was present in fair quantity in every sample taken during the month on the fishing grounds (see Table I). In 1907, on the other hand, it had almost completely disappeared, and as may be seen from the Plankton Tables (Table II), zooplankton was represented by merely a few species of Copepods in extreme abundance. The comparative symbol "cc" shown on the tables for certain samples (Nos. 52, 53, 54, 55) hardly sufficiently indicates the large quantities of the species occurring in the sample.

In comparing the plankton conditions during May of these two years, it may be mentioned that a far greater number of observations were taken in 1907 than in 1906. It is desirable, therefore, in draw- 
ing a close comparison, to consider only such observations as are common to the two years. These are furnished by the analyses of plankton samples taken at the mid-Channel and Bristol Channel stations (Stats. E. 5 and E. 6) during the May cruises of the International Plankton Investigations.

By the same method of comparison as adopted for other similar cases (see page 272) a curve was formed, showing the fluctuation of the principal zooplankton forming mackerel food. This curve (Fig. 1)

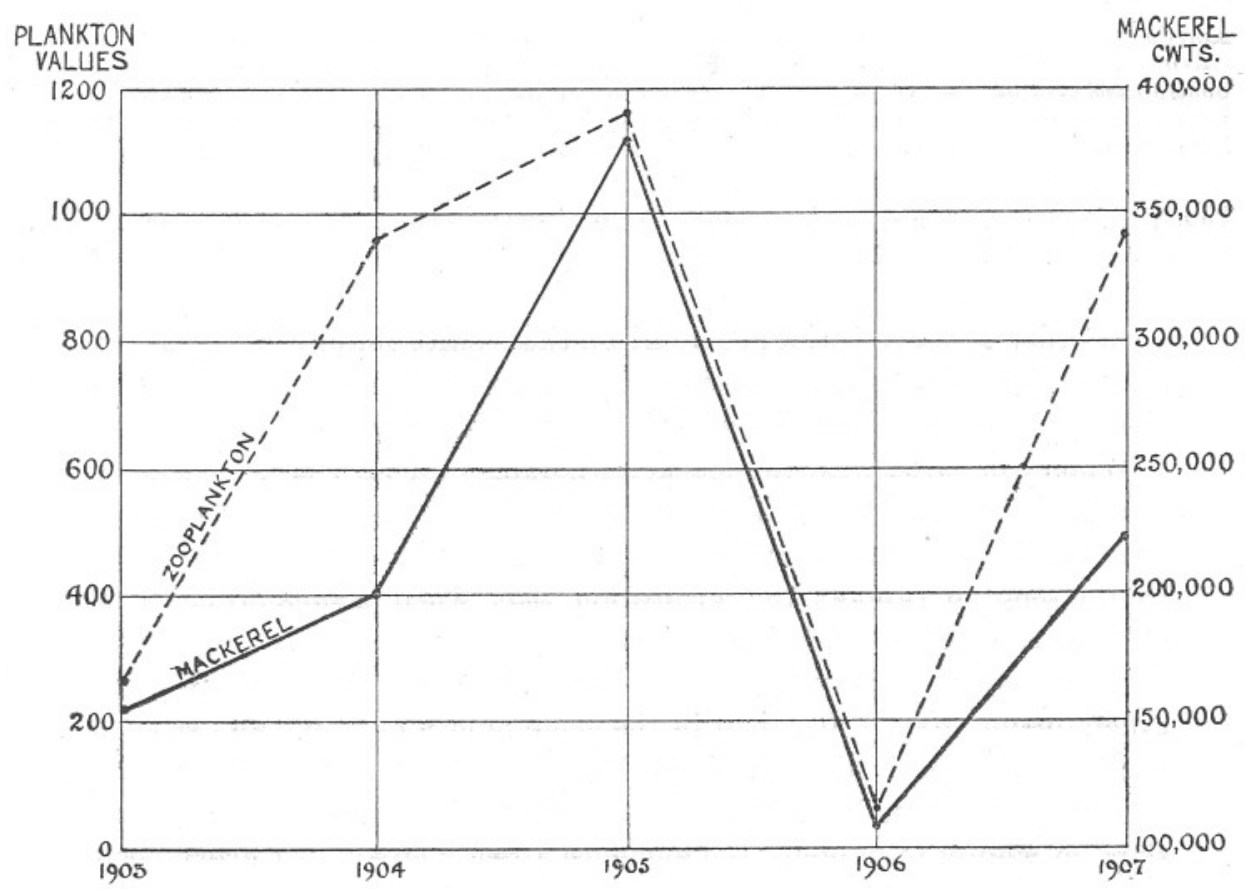

FIG. 1.-Curves showing, for the month of May, fluctuations in the quantities of mackerel landed, and of zooplankton observed at Stations E. 5 and E. 6.

Zooplankton: mean between Stations E. 5 and E. 6 for May-Dotted line. Mackerel landed during May-Continuous line.

shows the results of a mean between the analyses of the samples taken in surface hauls at the two stations, the following species only being taken into consideration: Acartia clausi, Calanus finmarchicus, Centropages typicus, Paracalanus parvus, and Pseudocalanus elongatus. 


\section{TABLE SHOWING FLUCTUATION OF PRINCIPAL ZOOPLANKTON AT STATIONS E. 5 AND E. 6.}

May Cruises. Years $1903-\gamma$ Inclusive. Surface Hauls only. FROM THE INTERNATIONAL BULLETINS.

The first column shows the comparative value sign, the second the adopted numerical value.

\begin{tabular}{|c|c|c|c|c|c|c|c|c|c|c|c|c|c|c|c|c|c|c|c|c|}
\hline \multirow{2}{*}{+} & \multicolumn{4}{|c|}{1903} & \multicolumn{4}{|c|}{1904} & \multicolumn{4}{|c|}{1905} & \multicolumn{4}{|c|}{1906} & \multicolumn{4}{|c|}{1907} \\
\hline & E. & 5 & E. & 6 & E. & 5 & E. & 6 & $\mathrm{E}$ & 5 & E. & 6 & E. & 5 & E. & 6 & E. & 5 & E. & 6 \\
\hline Species. & & & & & & & & & & & & & & & & & & & & \\
\hline $\begin{array}{l}\text { Acartia clausi } \\
\text { Calanus finmarchicus } \\
\text { Centropages typicus } \\
\text { Paracalanus parvus } \\
\text { Pseudocalanus } \\
\quad \text { elongatus }\end{array}$ & $\begin{array}{l}- \\
\mathrm{c} \\
+ \\
\mathrm{r} \\
\mathrm{c}\end{array}$ & $\begin{array}{l}- \\
100 \\
10 \\
- \\
100\end{array}$ & $\begin{array}{c}\mathrm{c} \\
\mathrm{c} \\
- \\
\mathrm{r} \\
\mathrm{c}\end{array}$ & $\begin{array}{l}100 \\
100 \\
- \\
\overline{100}\end{array}$ & $\begin{array}{c}- \\
\mathrm{cc} \\
\mathrm{r} \\
\mathrm{c} \\
\mathrm{c}\end{array}$ & $\begin{array}{c}500 \\
- \\
100 \\
100\end{array}$ & $\begin{array}{c}\mathrm{c} \\
\mathrm{cc} \\
+ \\
\mathrm{c} \\
\mathrm{c} \mathrm{c}\end{array}$ & $\begin{array}{c}100 \\
500 \\
10 \\
100 \\
500\end{array}$ & $\begin{array}{l}\mathrm{r} \\
\mathrm{cc} \\
\mathrm{cc} \\
\mathrm{c} \\
\mathrm{c}\end{array}$ & $\begin{array}{l}- \\
500 \\
500 \\
100 \\
100\end{array}$ & $\begin{array}{l}+ \\
\mathrm{c} \\
\mathrm{rr} \\
\mathrm{cc} \\
\mathrm{cc}\end{array}$ & $\begin{array}{c}10 \\
100 \\
- \\
500 \\
500\end{array}$ & $\begin{array}{l}\mathrm{rr} \\
+ \\
- \\
+ \\
\mathrm{c}\end{array}$ & $\begin{array}{c}- \\
10 \\
- \\
10 \\
100\end{array}$ & $\begin{array}{c}\mathrm{r} \\
\mathrm{rr} \\
- \\
\mathrm{rr} \\
\mathrm{rr}\end{array}$ & $\begin{array}{l}- \\
- \\
- \\
-\end{array}$ & $\begin{array}{l}\mathrm{c} \\
\mathrm{cc} \\
\mathrm{c} \\
+ \\
\mathrm{cc}\end{array}$ & $\begin{array}{c}100 \\
500 \\
100 \\
10 \\
500\end{array}$ & $\begin{array}{l}\mathrm{cc} \\
\mathrm{c} \\
\mathrm{c} \\
\mathrm{r} \\
+\end{array}$ & $\begin{array}{c}500 \\
100 \\
100 \\
- \\
10\end{array}$ \\
\hline $\begin{array}{l}\text { Total num. value } \\
\text { Mean value }\end{array}$ & & 210 & 255 & 300 & & 700 & $955^{1}$ & 1210 & & $\begin{array}{r}1200 \\
1 .\end{array}$ & 155 & 1110 & & 120 & 60 & 0 & & $\begin{array}{r}1210 \\
\mathrm{c}\end{array}$ & $960^{7}$ & 710 \\
\hline
\end{tabular}

In order to form a wider comparison the results obtained from all the May cruises since the commencement of the International Investigations in 1903 have been included in the present curve.

When compared with the mackerel landings for May as provided by the official statistics, it will be seen that the correlation between fluctuation of zooplankton and that of the fishery is very marked. This would tend to support the suggestion that when zooplankton is in abundance on the fishing grounds mackerel are numerous.

As already mentioned many more plankton observations were taken during May, 1907, than in the same month of 1906, and as such were actually derived from the fishing area, west and south-west of Scilly (see Samples Nos. 52-55, Table II), they are of value, tending as they do wholly to support the evidence already cited. At every position within the fishing area the samples taken during a ten-minute surface haul were bulky, being composed for the greater part of two or three species of Copepods, viz. Acartia clausi, Calanus finmarchicus, and Pseudocalanus elongatus, the two latter more particularly, to the almost complete exclusion of other organisms. At one position west of Scilly (S. 52, Table IV), a ten-minute surface tow-netting more than half filled a sample jar of capacity approximately $300 \mathrm{cc}$. with these two species, in comparatively even proportion. In connection with this fact it may be mentioned that a steam drifter fishing ten miles west of this position on the same night (May 16, 17) landed four lasts of fish at Newlyn the next morning.

It is perhaps unnecessary to cite further instances of a similar character. The Food and Plankton Tables and Fluctuation Curve 
speak for themselves in support of the theory that the quantity of zooplankton occurring on the fishing grounds materially affects the fishing; the more food the more fish, and vice versa.

Before leaving the consideration of the present matter, it is desirable to draw attention to the relation of phytoplankton to zooplankton during May, for the years 1903-7 inclusive. This can best be done by an examination of a curve showing the fluctuation of phytoplankton at the same stations and formed by the same method (Fig. 2).

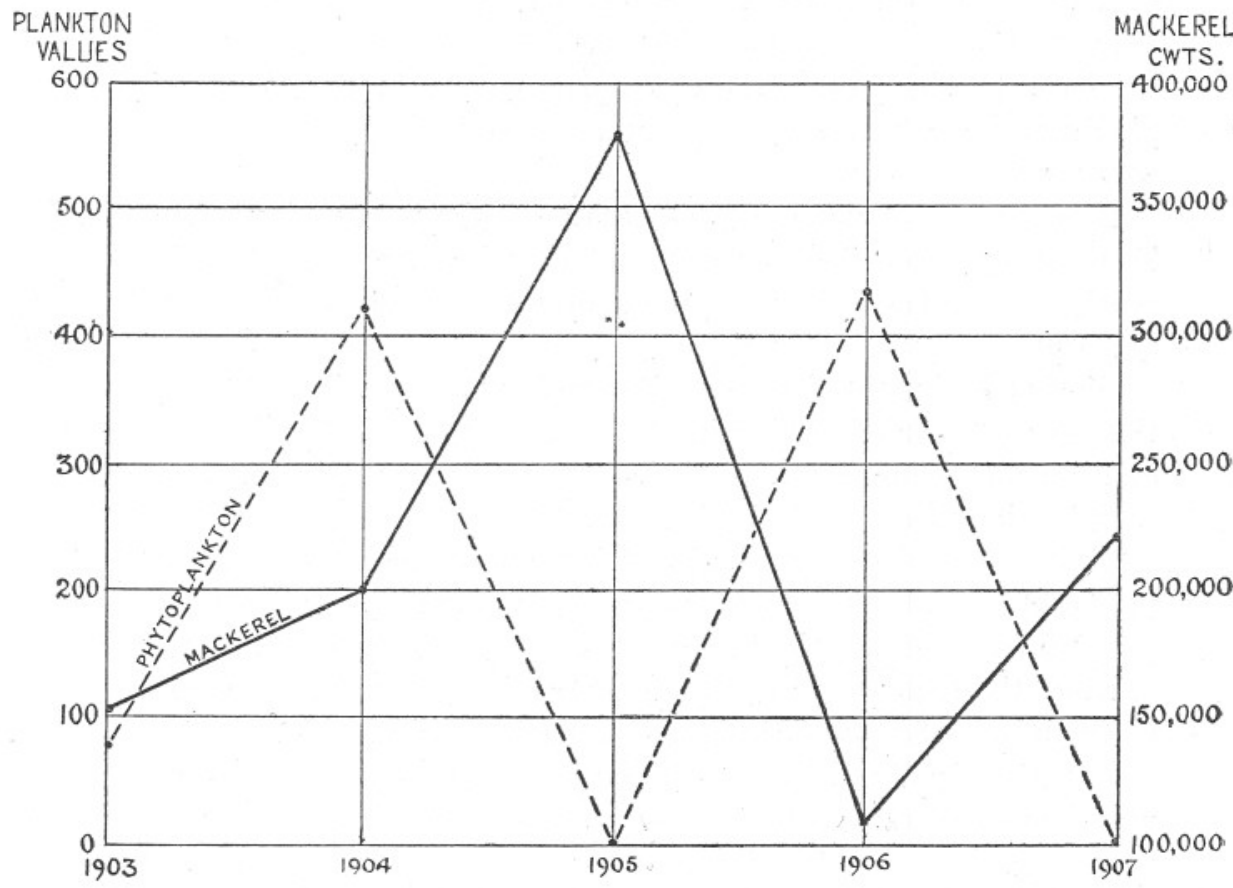

FIG, 2,-Curves showing, for the month of May, fluctuations in the quantities of mackerel landed and of phytoplankton observed at Stations E. 5. and E. 6.

Phytoplankton: mean between Stations E. 5 and E. 6 for May-Dotted line. Mackerel landed during May-Continuous line.

In the present example, however, it was found necessary to take every species of phytoplankton into consideration. In this it will be seen there appears to be almost a direct inversion of the zooplankton curve. There is an exception, however, in 1903, in which year plankton generally is low.

We have seen that there appears to exist a marked correlation between fluctuation of zooplankton and that of the fishery. It will be admitted that the fluctuation of zooplankton need not necessarily entail 
a diametrically opposite fluctuation of phytoplankton, but we shall not here attempt to discuss the causes which promote paucity or abundance of phytoplankton.

But little is known at present of the food of Copepods, and the inversion of the phytoplankton curve in comparison with that of zooplankton cannot be offered in any way as evidence that Diatoms, Peridiniales, and other comparatively large protophyta taken in tow-nettings are the food of Copepods. Therefore the paucity of phytoplankton correlating to a large extent with the abundance of mackerel (Fig. 2) need not at present be considered as other than additional evidence to show that where zooplankton is in excess of phytoplankton mackerel are more numerous-the subject of a former paragraph.

Briefly now to summarize the results of the present investigations. The following considerations are submitted as forming the principal points of correlation between the plankton and mackerel during 1906 and 1907.

(i) That during the three months forming the more important part of the spring mackerel fishing in the west part of the English Channel and Bristol Channel, viz. April, May, and June, mackerel appear to feed for the greater part on plankton.

(ii) That the plankton organisms observed in the stomach contents of mackerel are also to be found in tow-nettings taken on the same position from whence the fish are derived. Further, that in a majority of cases, the relative quantities or proportions of such species are also common to both tow-nettings and stomach samples.

(iii) That in April of the two years under present consideration, where zooplankton was in excess of phytoplankton mackerel were more numerous.

(iv) That the abundance or paucity of zooplankton during a certain number of years (1903-7) appears to be correlated with the greater or less abundance of mackerel.

\section{THE "START” MACKEREL FISHERY.}

\section{GENERAL CONDITIONS IN 1907.}

From the reports of fishermen at Plymouth and Newlyn, together with information derived from a fish salesman agent at Boulogne, it appeared that from the end of December, 1906, and throughout January, February, and the greater part of March, a regular and profitable trawl fishery for mackerel was carried on in an area of 20 to 40 miles S.S.W. to S.E. of Start Point. 
Cligny, in a paper entitled "Les prétendues migrations du maquereau," has pointed out that the existence of mackerel congregated in dense shoals on the bottom in this particular area, was first brought to light during the winter of 1901, and that since that time a regular trawling industry for mackerel by means of a specially designed trawl has been carried on by the Boulogne fishermen, in the early spring.

In regard to this fishery, it has been stated by many fishermen at Plymouth that the best catches are made during the daytime, night trawling being often entirely unproductive.

From a consideration of this fact, the fishermen at first were of the opinion that the mackerel rose to the surface at night, and a certain number of boats shot drift-nets in the area where it was known that successful trawling during the day had been carried out. In every instance, however, the catches made at the surface were very light, and the practice was soon abandoned owing to the risk of damage to nets.

Toward the end of March, 1907, a Plymouth steam trawler, the Condor, was furnished with a special mackerel trawl, constructed in France; but losing this net on her first shot on the mackerel ground, an ordinary otter trawl was employed, with the result that a catch of nearly eight thousand mackerel was made, fish measuring $12 \frac{1}{2}$ to $14 \mathrm{in}$. in length. A Boulogne fisherman, who was superintending this fishing, expressed an opinion that had the trawl been a regular mackerel trawl, and the speed capability of the vessel greater, a far larger catch would have been made. This fishing was carried out, on a position roughly 25 miles S.W. of Start, on the 24th of March. Five days later a Brixham smack landed nine mackerel caught amongst other fish 20 miles S.E. of Start. From information received from Boulogne* it would appear that in 1907, throughout January, February, and the earlier part of March, the French trawling fleet, numbering nearly thirty vessels, were landing regular catches of sixty thousand down. During the third week of March, however, the catches rapidly decreased, until at the end of the month scarcely ten per cent of the former catches were landed, and the fishery was therefore discontinued.

Cligny, in the paper mentioned above, remarks on the close shoaling within certain limited areas on the ground in question, and this condition has been further evidenced during 1907 by statements made by the Boulogne fisherman in charge of the Condor's operations, who mentioned that of two vessels trawling within half a mile of each other, on a parallel course, the one would often obtain a large catch, whilst

* A series of telegrams giving daily market reports, for the use of which the writer is indebted to Mr. R. H. Palmer. 
the other would fish lightly. The same fisherman, moreover, stated that he considered the shoals to lie parallel with the shore line.

[Note.-Amongst the fishing community at Plymouth and Newlyn a considerable diversity of opinion at one time existed in regard to the form and construction of the mackerel trawl. It may, therefore, be desirable to state that the writer was informed by Mr. Chant, the owner of the Condor, that the following details of construction, present in the net which was lost, constitute the essential points in which the mackerel trawl differs from an ordinary otter trawl.

Not being in a position to show the actual specifications of the trawl in question, Mr. Chant stated that the otter boards were heavier, the length of the foot rope was 92 feet (less than that of an ordinary otter trawl, which is usually 120 to 130 feet), and that the cod end was longer and bred of a finer mesh, viz. one inch. These points alone, he explained, constituted the difference in construction. The main point of the successful manipulation of the trawl, he stated, appeared to lie in the fact that, when trawling is proceeding at the pace of three miles an hour, the length of hawser employed should be five times the depth of the water.

With this length of hawser, he explained, together with the extra weight of the otter boards, there is no chance of the trawl leaving the ground, although it does not work so heavily as an ordinary trawl would, at the usual pace of two miles an hour.

Mr. Chant further stated that the mackerel taken by the Condor were caught in an ordinary otter trawl, the cod end of which had been backed with netting of a finer mesh.]

\section{THE PHYSICAL AND BIOLOGICAL CONDITIONS OBSERVED ON THE START MACKEREL GROUND.}

As a result of a series of observations taken from the Oithona. at two positions on the mackerel trawling ground on March 27th, 1907, the following is a summary of the chief physical and biological conditions then observed within the area :-

First Position.-15 miles S.W. from Start Point.

Depth, 38 fathoms.

Condition of bottom, fine sand.

Temperatures: surface, $9 \cdot 25^{\circ}$.

11 fathoms, $8 \cdot 35^{\circ}$.

22 fathoms, $8 \cdot 26^{\circ}$.

Bottom, 38 fathoms, $8 \cdot 3^{\circ}$. 
Second Position.-21 miles S. $\times$ W. $\frac{3}{4}$ W. of Start.

Depth, 39 fathoms.

Condition of bottom, coarse sand, fine gravel.

Temperatures: surface, $9 \cdot 45^{\circ}$.

16 fathoms, $8 \cdot 65^{\circ}$.

Bottom, 39 fathoms, $8 \cdot 65^{\circ}$.

General condition of plankton* taken by coarse and fine nets :-

Bottom (39 fathoms). Four species of Copepods, chiefly Temora longicornis, not abundant; few other metazoa, including Oikopleura dioica, rare.

Phytoplankton in excess of zooplankton, composed largely of diatoms, Lauderia borealis and Chaetoceras densum, both common.

Fourteen other species of diatoms observed.

Surface plankton, similar in every respect to the bottom samples but slighter in bulk.

Petersen trawl samples from surface, midwater and bottom were composed largely of several species of amphipods: Aphereusa bispinosa, very abundant, Bathyporeia pelagica, rare, Euthemisto gracillipes, rare, Monoculodes sp., rare, Paratylus vedlomensis, rare, Stenothoë marina, rare, Urothoe elegans, rare, etc. Schizopods, viz. Anchialus agilis, rare, Gastrosaccus spinifer, rare, Mysidopsis angusta, rare, and $M$. gibbosa, very rare. A fair number of post-larval fish were also taken, including Clupea harengus, plentiful, Pleuronectes microcephalus, common, Solea variegata, rare, etc.

An unsuccessful attempt was made to obtain mackerel in the otter trawl. The following species, however, were taken after a two hours' haul: Arnoglossus laterna and A. megastoma, Callionymus lyra, Gadus minutus, G. luscus, and G. merlangus, Gobius quadrimaculatus, Pleuronectes platessa, Raia blanda, Rhombus laevis, Solea variegata, and S. lascaris, Trachinus draco, Trigla cuculus, T. gurnardus, T. hirundo, and T. lineata, Zeus faber, together with several invertebrates.

\section{GENERAL CONDITIONS OBSERVED IN STOMACHS OF MACKEREL TRAWLED} ON THE START GROUND.

The contents of six stomachs were examined from the fish taken by the Condor on March 24th, 1907. A general determination based upon the six samples will be found in the Food and Plankton Tables (Table V), Sample No. 24. It is desirable, however, to describe the present material more particularly. In the six samples there appeared to be two distinct types of food, together with intermediate stages, in

\section{* See Plankton Tables, Sample No. 38.}

NEW SERIES.-VOL. VIII. NO. 3 , 
which the one converged into the other, forming, so to speak, a mixed sample. In one stomach only there occurred a pure zooplankton sample, consisting almost entirely of Temora longicornis; three other species of Copepods were observed in extreme scarcity, viz. Centropages typicus, Paracalanus parvus, Pseudocalanus elongatus, together with a few Caridid larvæ and Amphipod remains. This sample alone constituted the one extreme; the other, which may be considered as phytoplankton, was represented by three slight samples, which were composed mainly of a number of plankton diatoms (Lauderia borealis and Chaetoceras densum principally), together with a few bottom forms such as Rhabdonema sp., forming with an indeterminable quantity of Phococystis globosa a glutinous mass. Entangled in this material were observed also a few Temora longicornis and the three other species of Copepods above mentioned, together with a large number of Oikopleura dioica.

In the case of the two mixed samples, two slightly different types of food were observed. In the one Temora longicornis occurred fairly plentifully throughout the stomach contents, which otherwise were composed of the phytoplankton mass, as already described. In the second instance Temora longicornis formed an almost pure sample in a layer deposited above the phytoplankton. In connection with Oikopleura dioica it is interesting to note the following points. It occurred in greater abundance in the stomach samples showing phytoplankton and mixed material than it did in the tow-nettings taken from the Oithona (see Table No. II, Sample No. 38). Secondly, it was not observed at all in the sample composed entirely of Temora longicornis; and lastly in the mixed sample already referred to, where Temora was deposited in a layer, it did not occur amongst the Copepod material, but was plentiful in the lower layer of phytoplankton. These points alone in connection with Oikopleura dioica appear to constitute the sole difference existing between the plankton samples and stomach material.

\section{CONCLUSION.}

It has been suggested by several previous authors* that the migrations of the mackerel are not so extensive as hitherto generally supposed. Cligny, in the paper already referred to, states that, as far as his observations extend, mackerel return year after year, at the close of the shoaling season, to certain confined areas not far

* Allen, "Report on the Present State of Knowledge of the Habits and Migrations of Mackerel” (Scomber scomber), p. 26, M.B.A. Journal, vol. v. (N.S.).

Garstang, "On the Variation Races and Migrations of the Mackerel" (Scomber scomber), p. 286, ibid.

Cligny, Les prétendues migrations du Maquereau. 
removed from the spawning grounds. At present only a few of these winter quarters are known to fishermen. Unless, therefore, certain other areas in the Channel exhibiting physical features common to the Start ground were thoroughly investigated, any attempt to suggest a reason for the preference of the fish for such particular spots would be based upon insufficient evidence.

In reviewing the foregoing observations upon the physical and biological conditions of the Start ground toward the close of the trawling season, it is desirable to draw attention to the following points: (1) that these bottom shoaling fish appeared to be feeding largely upon plankton; (2) that the plankton species observed in the stomach contents were common to the tow-nettings taken within the fishing area; (3) that Oikopleura dioica occurred in great abundance in stomach contents composed largely of phytoplankton, but in those containing a considerable quantity of zooplankton it was scarce, and further that, under the former circumstance, it was far more plentiful than in the tow-nettings taken within the fishing area; $(4)$ that the tow-nettings taken on the bottom showed a greater bulk of material than those from the surface.

\section{FISHERMEN'S "SIGNS."}

Amongst the west and east country fishermen there are generally recognized certain distinctive types of water in which mackerel are said to occur more or less abundantly. According to the men's statements, the colour and appearance of the water, its smell, and possibly upon occasion the presence of certain marine birds, comprise the only indications by which the drifter is guided in making choice of his position.

That these "signs," as they are termed, are the outcome of experience there can be no question, and the greater or less capability for interpreting them makes a better or worse fisherman. An instance occurred on one occasion when I was at Mevagissey, when one fisherman shot his nets a few miles to the landward of the rest of the pilchard fleet and secured a top catch; when questioned as to his reasons for doing so he explained that the signs at that particular position were altogether better than any that he had seen the previous night farther out. At other times I have heard a fisherman state that he could not hope for even a fair catch, as the class of water was entirely unsuitable, and on hauling nets this surmise has been found correct in every instance.

Before proceeding to treat the matter in detail it will be well to 
summarize the result of systematic inquiry made amongst the fishermen in regard to their views upon the subject, and to detail the different characteristics of the various types of water as described by the fishermen themselves.

"Stinking Water" is of a dull leaden colour even in bright sunlight, so dense that a man looking over the side of a sailing drifter cannot. see down to the keel. It possesses, according to the fishermen, a distinctly noxious smell, which has been described as similar to that of decaying seaweed. The men are agreed that mackerel are not to be found in such water; but one informant stated that scad or horse mackerel are often present in fair-sized shoals.

"Grey Water" is somewhat similar to the foregoing, but does not. possess an unpleasant smell. Mackerel are never numerous in such water.

"Blue" and "Green Water" are both suitable for good shoals of fish. They differ, according to the fishermen, merely as regards colour. Both are so clear that the keel of the vessel can be seen distinctly. Both varieties are the usual types of water found in the western area in the early part of the season, right up to the first or second week in May. The fishermen are agreed in considering either type sufficiently promising to allow of fishing with some prospect of a fair catch.

"Yellow Water" is considered to be the best of any. This, according to the statement of many fishermen, exhibits the following characteristics. It seldom appears before the beginning of April, and more often not until the last week of that month. It is of a distinctly yellow tint, and rather dense when viewed either in sunlight or under a dull sky; often it appears in patches of greater or less extent. In certain years the sea west of Scilly has been almost entirely of this type of water. It appears, according to certain statements, to be teeming with "minute animal life." The fishermen agree in stating that the largest catches are always made in such water, and that it is not usual for an unproductive shot to be made, although, by the statement of several fishermen interrogated upon the point, it would appear that light catches are occasionally made in the best type of yellow water. Certain fishermen consider that the colour of the water is not due to the excreta of mackerel, but to the general colour of the "swarms of water fleas," whilst others on account of its density contend that it is coloured by excrement of mackerel.

Other "signs."-Apart from the characteristic of smell invariably associated with so-called "stinking water," the generality of fishermen are agreed that a shoal of drift fish may be detected by their smell. This is more strongly pronounced in the case of pilchards, but, with 
mackerel shoaling densely, the fishermen state that there is no mistaking it. An oily appearance at the surface of the water generally occurring in "splats," i.e. patches, is also said to be a sure indication of drift fish.

A milky appearance of the surface generally occurring in inshore waters, where there is no addition of china clay to the water, is associated by the fishermen with shoals of small mackerel, the milky appearance being due, it is stated, to excrement.

"Signs" of shoaling fish offered by the presence of sea-birds preying upon them occur more frequently, according to the fishermen's statement, in inshore waters, and the point is one which has already been described by previous writers, and need not therefore be discussed here.

COMPARISON OF "SIGNS" OFFERED BY DIFFERENT TYPES OF WATER WITH THE CONDITION OF PLANKTON OCCURRING IN SUCH WATER.

In order to endeavour to ascertain to what extent these colour "signs" are produced by plankton conditions, a number of plankton samples were taken for me in 1906-7 by fishermen, and labelled with reference to the particular type of water from which they were derived.

“Stinking Water."-Sample No. 39, Plankton Tables, was taken by myself on April 10th, 1907, in an area of water termed by the fishermen "stinking," which, it was stated, extended from the Lizard to Land's End in a zone of varying width about ten miles or more from the shore. At the particular position at which it was taken, 6 miles N.W. $\times$ W. of Lizard, the fishermen were agreed in stating that the water was a fair sample of the "stinking" type, and that it would be useless to shoot in it. The colour and characteristics generally were in accordance with the description already given; but although the fishermen were agreed in saying that there was an obnoxious smell, I was unable myself to detect it. The analysis of the sample showed (by the method of comparison described in a former section) a moderate preponderance of phytoplankton over zooplankton, but the total bulk of the sample was comparatively small. As will be seen on reference to the Plankton Tables, the phytoplankton was mainly composed of diatoms, of which Chaetoceras boreale and $C$. densum were both common. Phaeocystis globosa appeared to be rare. The zooplankton comprised three Copepods, Acartia clausi, Oithona similis, and Pseudocalanus elongatus, moderately common. Calanus finmarchicus was rare.

"Green Water."-It will be convenient at this point to compare the foregoing with another sample (No. 40, Plankton Tables) taken on the same date outside the "stinking water." This was at a position 16 miles 
S.W. of Lizard, where a catch of 500 mackerel was made. The water appeared to be of a distinctly different type of a clear green tint. This was considered by the fishermen to be in every way suitable for the presence of shoaling fish. The examination of the sample showed the following points. Zooplankton was in excess of phytoplankton. This condition, however, was not brought about by a very pronounced decrease in the quantity of diatoms, but by the increased number of Copepods. Calanus finmarchicus, which was rare in the former sample, was common in the present one.

Between Samples 24 and 26, Plankton Tables, the former of which was taken by fishermen in "green water" and the latter in "blue," and from widely dissimilar positions, viz. 35 miles S.S.W. of Newlyn and 18 miles south of the Lizard, on May 5th and 10th respectively, there did not appear to be any striking points of difference. In each zooplankton was in excess of phytoplankton. The relative quantity of phytoplankton of the "green water" sample, however, was greater than that of the "blue water," although in the latter there was a slight quantity of Phaeocystis globosa, which was absent from the former. A greater variety of diatoms was observed in the "blue water" sample than in the "green," the higher proportion in the latter, already referred to, being due to two species, Rhizosolenia alata and R. styliformis, both plentiful.

In the main the zooplankton observed in each sample was similar. The Copepod Temora longicornis, however, occurred in the "blue water" sample, whilst it was absent from the "green"; but the more eastern distribution of the species described under a former heading would probably account for its absence in this sample of more western origin.

Samples 32 and 33, Plankton Tables, may be compared in a similar manner. They are taken later in the season, but present no striking dissimilarity.

No verified observations were taken in "grey water" except Sample 23 , which, as stated in a footnote, would appear to be unreliable.

“ Yellow Water."-In 1906, on May 20th, a sample was taken by fishermen in such water 40 miles S.W. of the Bishop. Unfortunately, however, the bottle containing the sample was broken in transit, and in consequence the exact nature of the plankton was difficult to determine. It appeared, however, to be composed very largely of the two Copepods Calanus finmarchicus and Pseudocalanus elongatus, and from the appearance of the remains it seemed to have been a very bulky sample.

This sample formed the sole observation from "yellow water" furnished by fishermen during 1906 and 1907. Throughout May, 1907, 
however, when the sea west of Scilly was, according to the fishermen's statement, teeming with mackerel, "yellow water" was commonly met with on the fishing grounds. An examination of the Samples 50 to 57 (Plankton Table No. II), all of which were taken either adjacent to or on the fishing area during the international plankton cruise May, 1907, will serve to show that throughout the area covered the samples taken showed a certain similarity. Phytoplankton was entirely absent and the zooplankton was confined almost entirely to three or four principal forms, of which Calanus finmarchicus and Pseudocalanus elongatus were the most important.

At one station, $49^{\circ} 49^{\prime} \mathrm{N} . \times 6^{\circ} 59^{\prime} \mathrm{W}$. (Sample No. 52), the sea was considered to be of a decidedly yellow tint, according to the statement of Mr. D. J. Matthews, the leader of the expedition, and an analysis of the very bulky sample showed that it was composed almost entirely of the two species mentioned above, in almost equal abundance.

The possible inferences which may be drawn, therefore, from the consideration of the foregoing observations can be briefly summed up as follows:-

That in the "stinking water" sample, phytoplankton was in excess of zooplankton, but that there was no evidence to show from whence colour or smell were derived, beyond evidence of a negative character, which would tend to suggest that the smell did not arise from the condition of plankton. This suggestion is based upon the fact of an almost equal quantity of phytoplankton occurring in the case of the "green water" sample formerly referred to, "green water," according to the fishermen's statement, being invariably free from smell. The evidence offered by the analyses of "blue" and "green water" samples would suggest that the plankton taken in such water was of a type comprising a fair number of species in which, in the present examples, zooplankton was in excess of phytoplankton. From lack of observations, however, it cannot be suggested that this is always the case.

Finally, with regard to "yellow water," the somewhat conflicting opinions expressed by fishermen as to the causes which give rise to the colour, already explained, would suggest that the yellow tint is accounted for either by the presence of excrement arising from densely shoaling fish or from the presence in large numbers of certain Copepods. In view of the fact that several fishermen declare that light catches of mackerel may be taken in "yellow water," and the evidence offered by the analyses of certain plankton samples, it would appear to be more probable that the coloration arose from the latter cause. Were this view adopted, moreover, it would be strictly in accordance with the theory already discussed, of mackerel being abundant where food is plentiful. 
TABle No. I.-PLANKTON COLLECTED ON MACKEREL GROUNDS, 1906.

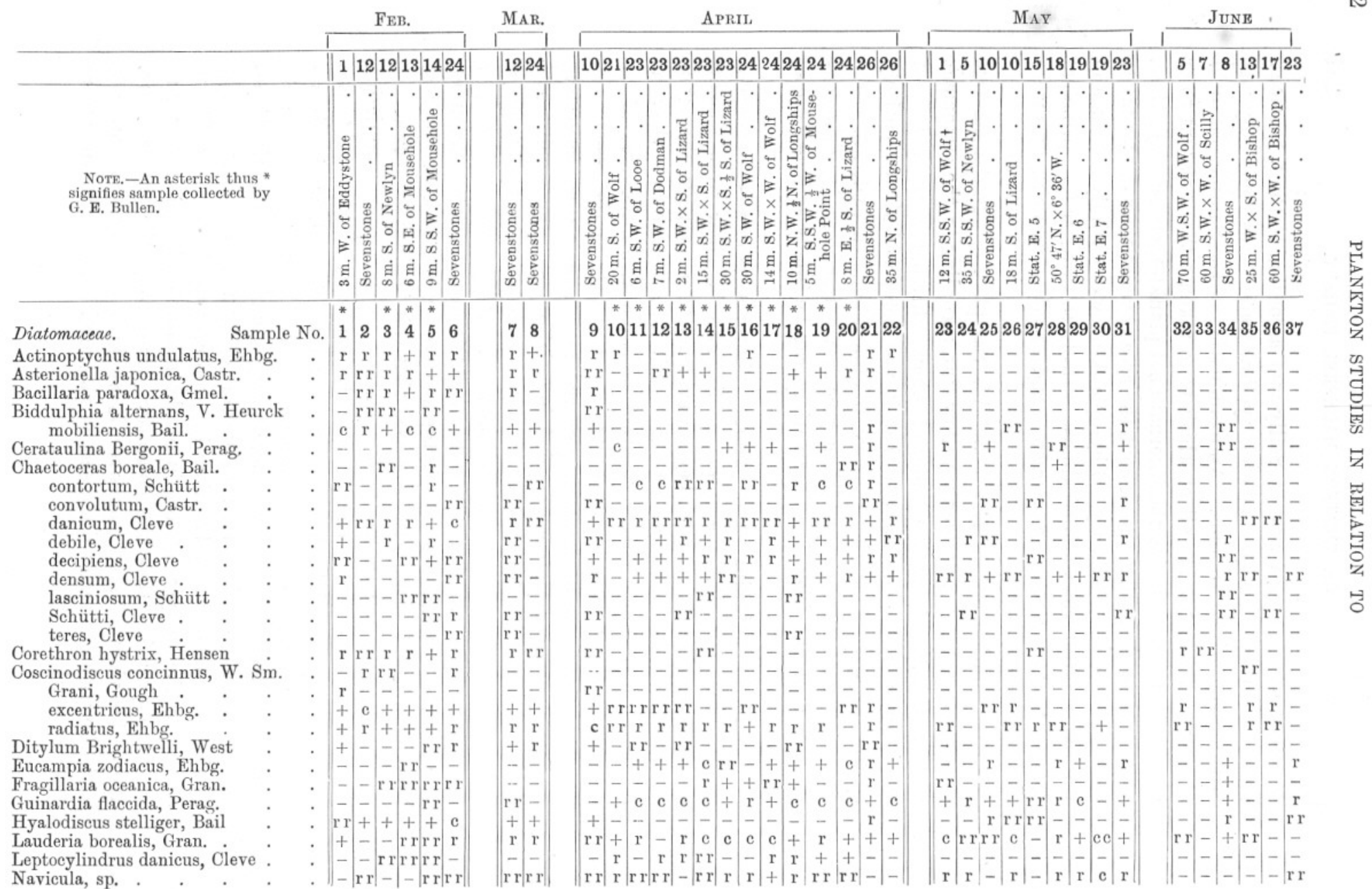


Nitzschia seriata, Cleve . Nitzschia, sp.

Paralia sulcata, Cleve

Pleurosigma, sp.

Rhizosolenia alata, Brtw.

delicatula, Cleve

semispina, Hens.

setigera, Brtw.

shrubsolei, Cleve

Stolterfothi, Perag.

styliformis, Brtw.

hebetata, Hens.

Skeletonema costatum, Cleve.

Streptotheca thamesis, Cleve

Thalassiosira decipiens, (Grun.) gravida, Cleve

Nordenskioldii, Cleve

Thalassiothrix nitzschioides, Grun.

Peridiniales.

Ceratium furca, Clap. and Lach. fusus, Ehbg.

horridum, Cleve

longipes, Bail. .

tripos, O. F. Mull.

Dinophysis acuta, Ehbg.

acuminata, Clap. and Lach.

rotundata, Clap, and Lach.

Diplopsalis lenticula, Bergh.

Peridinium conicum, Gran.

depressum, Bail.

ovatum, Pouchet

pallidum, Östf.

Steini, Jörg.

Prorocentrum micans, Ehbg.

Protophyta cetera.

Dictyocha fibula, Ehbg.

Distephanus speculum, Ehbg.

Halosphaera viridis, Schmitz

Phaeocystis globosa, Scheffel

Trochiscia Clevei, Lemm.

Trichodesmium (?) contortum, Wille.

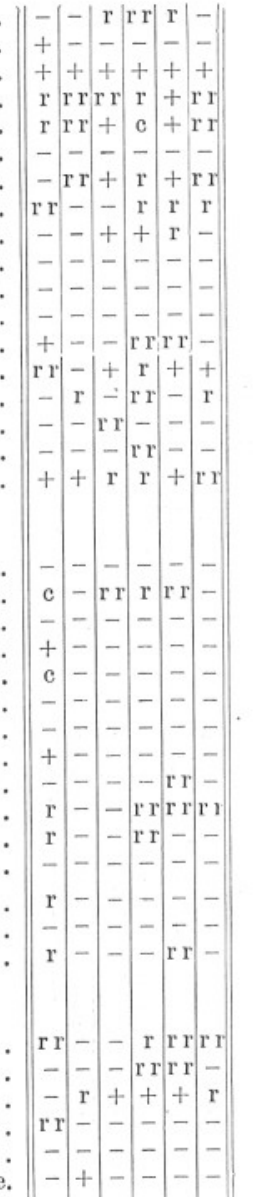

$\mid$\begin{tabular}{l|l}
- & -1 \\
- & - \\
+ & +
\end{tabular}

$++$

r r -

$-\mathrm{r} r$

$\mathrm{r} r \mathrm{r} r$

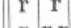

$\mathrm{r}$ r r

$\mathrm{rr}-|-| \mathrm{r}|-| \mathrm{r}|-|-|-|-|\mathrm{c}|-1-1-$ \begin{tabular}{lllllllllllllll}
- & $\mathrm{c}$ & $\mathrm{c}$ & $\mathrm{c}$ & $\mathrm{c}$ & + & $\mathrm{r}$ & $\mathrm{r}$ & $\mathrm{c}$ & $\mathrm{c}$ & $\mathrm{r}$ & $\mathrm{c}$ & $\mathrm{c}$ & $\mathrm{c}$ \\
\hline
\end{tabular}

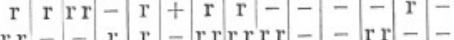
$\mathrm{r}$ c $\mathrm{c}+\mathrm{r}+\mathrm{c}+\mathrm{r}+\mathrm{c}+\mathrm{c}$ - r + rr - - - - - - $+\mathrm{c}+++\mathrm{c}++++\mathrm{c}$ c ++

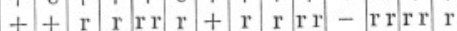
$\mathrm{r}---\mathrm{rr}++\mathrm{r}++++++$ - c $++++\mathrm{r}+\mathrm{c}$ c $\mathrm{c}++$ $\operatorname{rr}---_{-}-z_{-}-c_{-}$ $-\mathrm{r} r-\mathrm{r}_{-}--_{-}-\mathrm{r}-$

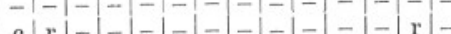

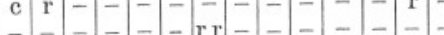

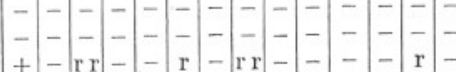

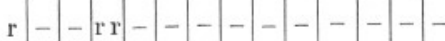
$++\mathrm{c}++\mathrm{r} r+\mathrm{r}++\mathrm{r} r$ $-\mathrm{rr}+\mathrm{r}-\mathrm{r}-\mathrm{r} r-$ $\mathrm{rrr}++++\mathrm{rr}-+\mathrm{rr}++\mathrm{r}-$ $\mathrm{rr}++\mathrm{r}-\mathrm{r} r \mathrm{rr}+\mathrm{r} r$

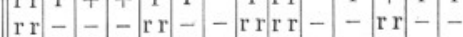

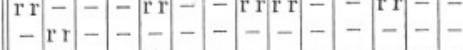

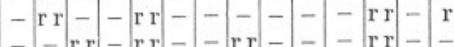

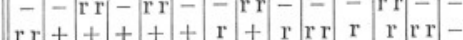
$\mathrm{rr}+++++\begin{array}{r}+ \\ - \\ +\end{array}$

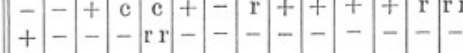
$+\mathrm{rr} r+\mathrm{r}-\mathrm{r}+\mathrm{r}++\mathrm{r} r$

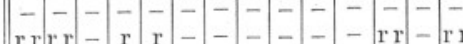
$\operatorname{rrrr}-\mathrm{r}$

$\mathrm{r}--\mathrm{rr}-\mathrm{rr}-\mathrm{rr}-\mathrm{rr}-\mathrm{rr}-$ $\mathrm{r}_{-}-\mathrm{rr}_{-} \mathrm{rr}-\mathrm{rr}_{-} \mathrm{rr}_{-}-\mathrm{rr}_{-}$ $++\mathrm{r}+\mathrm{r} r \mathrm{rr}+\mathrm{c}+\mathrm{r} \mathrm{r}++$ ? $\mathrm{c} \mathrm{ccecc}+\mathrm{r}$ r c cc c ececc

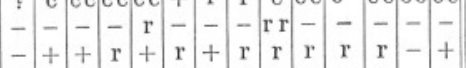
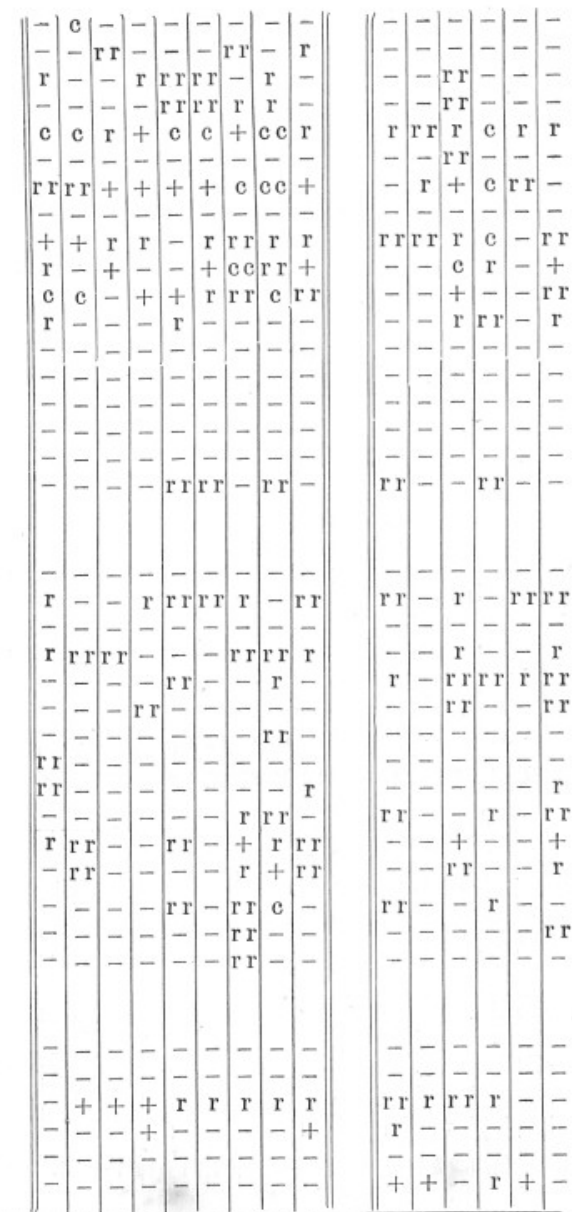

是 
Table No. I.-Continued.

Nore-An,asterisk, thus *
signifies sample collected by
G. E. Bullen.

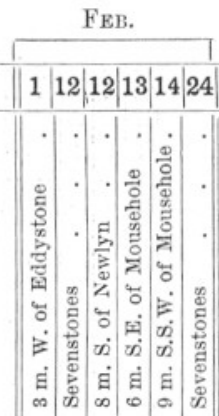

MAR. APRIL

MaY

JUNE

$|2| 24 \mid$

|| $10|21| 23|23| 23|23| 23|24| 24|24| 24|24| 26|26|$

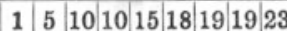

\begin{tabular}{|l|l|l|l|l|l|l|}
\hline 5 & 7 & 8 & 13 & 17 & 23 \\
\hline
\end{tabular}
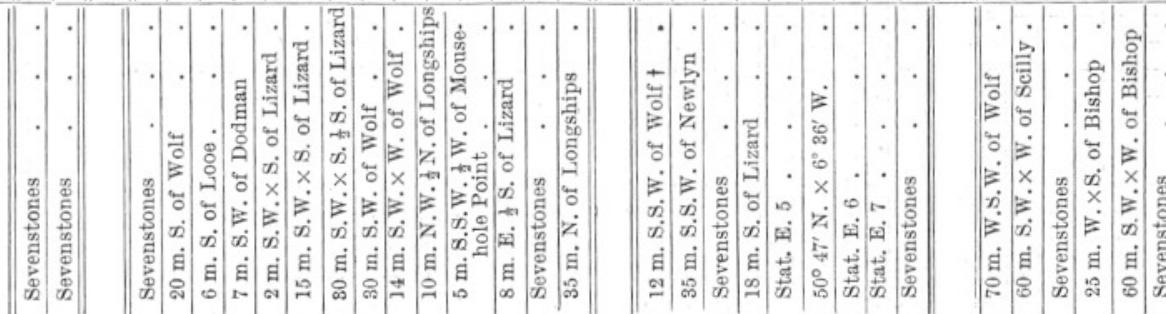

Protoroa.

Sample No.

\begin{tabular}{||l|l|l|l|l|l|}
$*$ & & $*$ & $*$ & $*$ & \\
1 & 2 & 3 & 4 & 5 & 6
\end{tabular}

Tintinnepsis beroidea, Stein

Noctiluca miliaris, Suriray

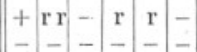

Caelenterata.

Muggiaea atlantica, Cunn.

Pleurobrachia pileus, Fabr.

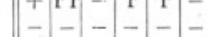

Corymorpha nutans, Sars

$+--+-$

Euphysa aurata, Forbes.

Hybocodon prolifer, Agassiz

Laodice calcarata, Agassiz

Margellium octopunctatum, Sar

Obelia nigra, E. T. Browne

Obelia sp.

Phialidum temporarium, E. T. Browne

Sarsia prolifera, M. Sars .

r r - - - -

Arachnactes Bournei, Fow

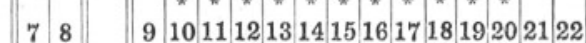

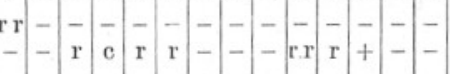

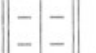

$2324252627282930 \quad 31$

$--{ }_{-}-\operatorname{rrrrrrr}-$

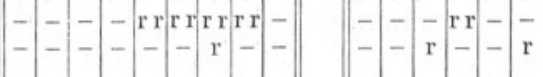

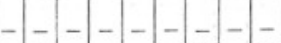

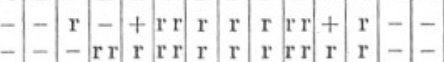

_

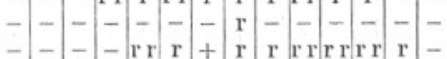

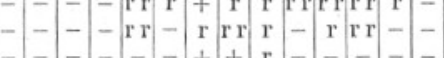

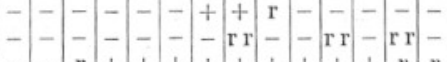

$-\mathrm{r}+++++++++\mathrm{rr}$

$++\mathrm{r}++++\mathrm{c}++\mathrm{r}+-\mathrm{rr}$

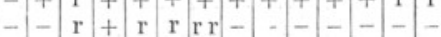

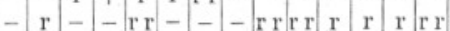

Echinodermata.

Auricularia

Bipinnaria

Echinopluteus

Ophiopluteus .

Vermes.

Annelida larivae

Sagitta bipunctata, Quojy and Ġaim,

Tomopteris helgolandica, Greef r r - r rrrr-

+ e $\mathrm{c}++\mathrm{c}$

1 1 - r r r r r rrrr

$++$

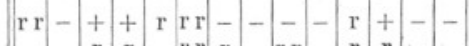

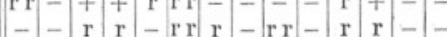

- r + + rrr r $-{ }_{-}-{ }_{-}+-$

$-r+r r r-r r+-$

$\mathrm{rr}++++++++++++++$ - c $\mathrm{c}$ c + c $\mathrm{c}$ c $+\mathrm{r}$ r +

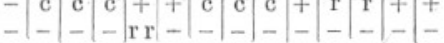
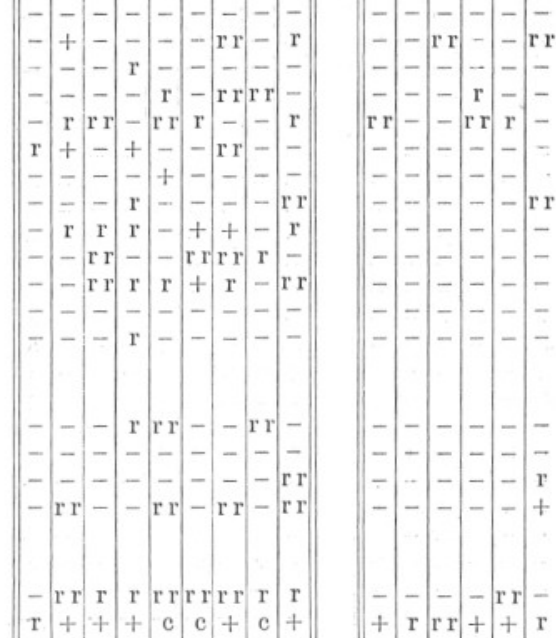

$+\mathrm{r} r \mathrm{rr}+\mathrm{r}$ \begin{tabular}{ll|l|l|l}
+ & $\mathrm{r}$ & $\mathrm{rr}$ & + & $\mathrm{r}$ \\
- & - & $\mathrm{r} r$ & -
\end{tabular} 
Acartia Clausi, Giesb

Anomalocera Pattersoni, $\dot{\mathrm{R}}$. Temp.

Calanus finmarchicus, Gunn

Candacia pectinata, Brady

Centropages typicus, Kroye

Euterpe acutifrons, Dans.

Isias clavipes, Boeck

Metridia lucens, Boeck

Microsetella atlantica, Brady

Oithone

plumifera, Baird

similis, Claus.

Paracalanus parvus, Claus.

Parapontella brevicornis, O. F. Mull.

Pseudocalanus elongatus, Boeck.

Temora longicornis. O. F. Mull.

\section{rustacea cetera.}

Anchialis agilis, G. O. Sars

Apherusa Clevei, G. O. Sars

Carididae larva

Cirripedia larvae

Euthemisto gracillipes, Norman

Evadne Nordmanni, Loven

Nauplius .

Nictyphanes Couchii, Bell

Podon intermedius, Lilljeb.

Zoeae

Megalopa stage .

\section{Mollusca.}

Clione limacina

Gasteropoda larvae.

amellibranchiata larvae

Limacina retroversa, Flem.
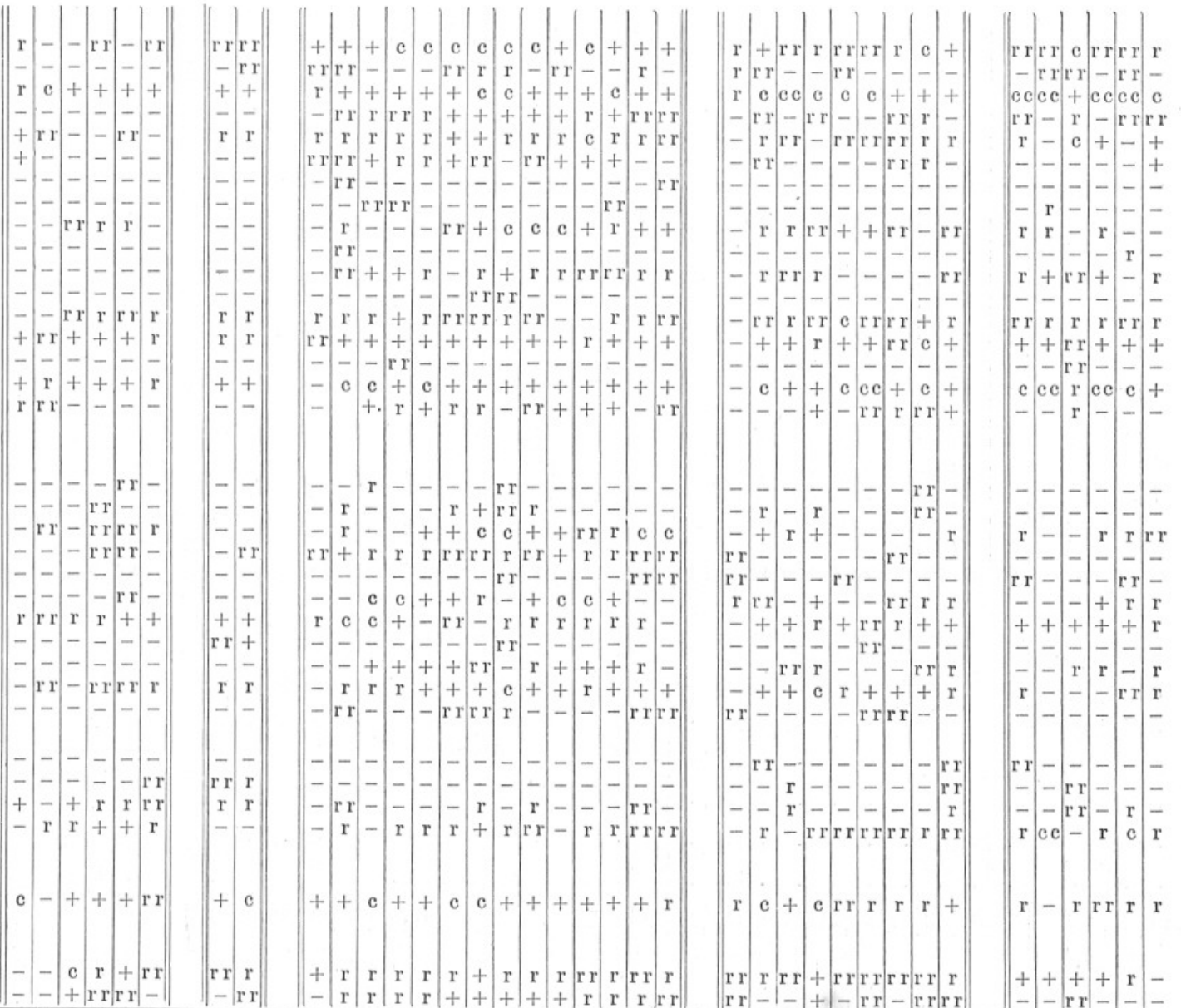

+ An unreliable sample taken by fishermen. 
TAble No. II.-PLANKTON COLLECTED ON MACKEREL GROUNDS, 1907.

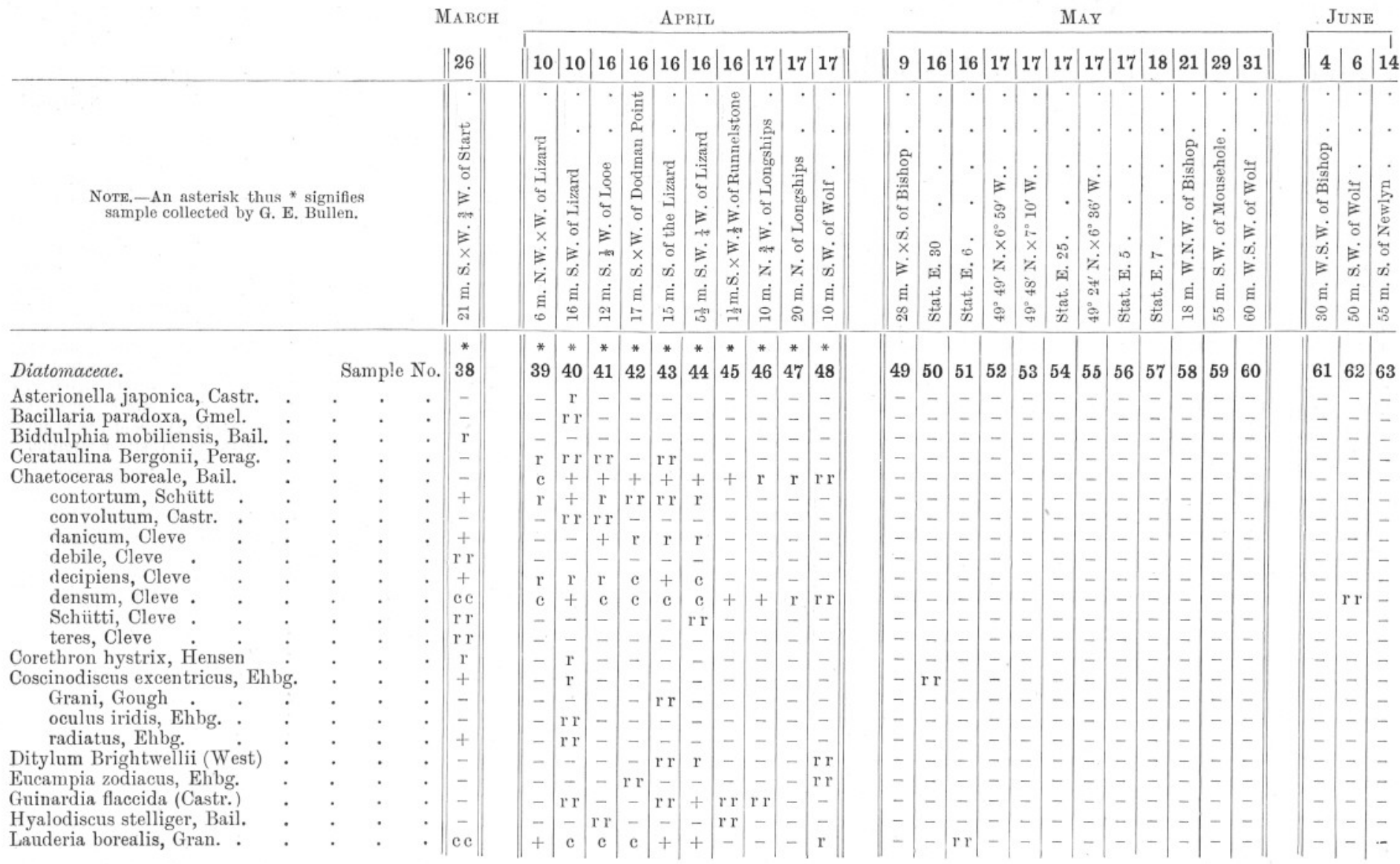


Nitzschia seriata, Cleve . Nitzschia sp.

Paralia sulcata (Ehbg.)

Pleurosigma sp.

Rhizosolenin alata, Btw. delicatula, Cleve

hebetata, Bail.

semispina, Hensen

setigera, Btw.

Shrubsolei, Cleve

Stoltefothii, Perag.

Skeletonema costatum (Greve.)

Streptotheca thamesis, Shrub.

Thalassiosira decipiens (Grun.)

gravida, Cleve Nordenskiöldii, Cleve

Thalassiothrix nitzschioides, Grun.

Peridiniales.

Ceratium furca (Ehbg.) fusus (Ehbg.)

longipes (Bail.)

tripos (O. F. Mull)

Dinophysis acuta (Ehbo

rotundata (Clap and Lachm.) Vanhöffeni

Diplopsalis lenticula, Bergh.

Gonyaulax polygramma, Stein.

Peridinium conicum, Gran.

depressum, Bail.

ovatum, Pouchet.

pallidum, Oste.

Steini, Jörg.

Prorocentrum micans, Ehbg.

\section{Protophyta cetera.}

Dictyocha fibula, Ehbg.

Distephanus speculum (Ehbg.)

Halosphaera viridis, Schmitz.

Phaeocystis globosa, Scherffel. .
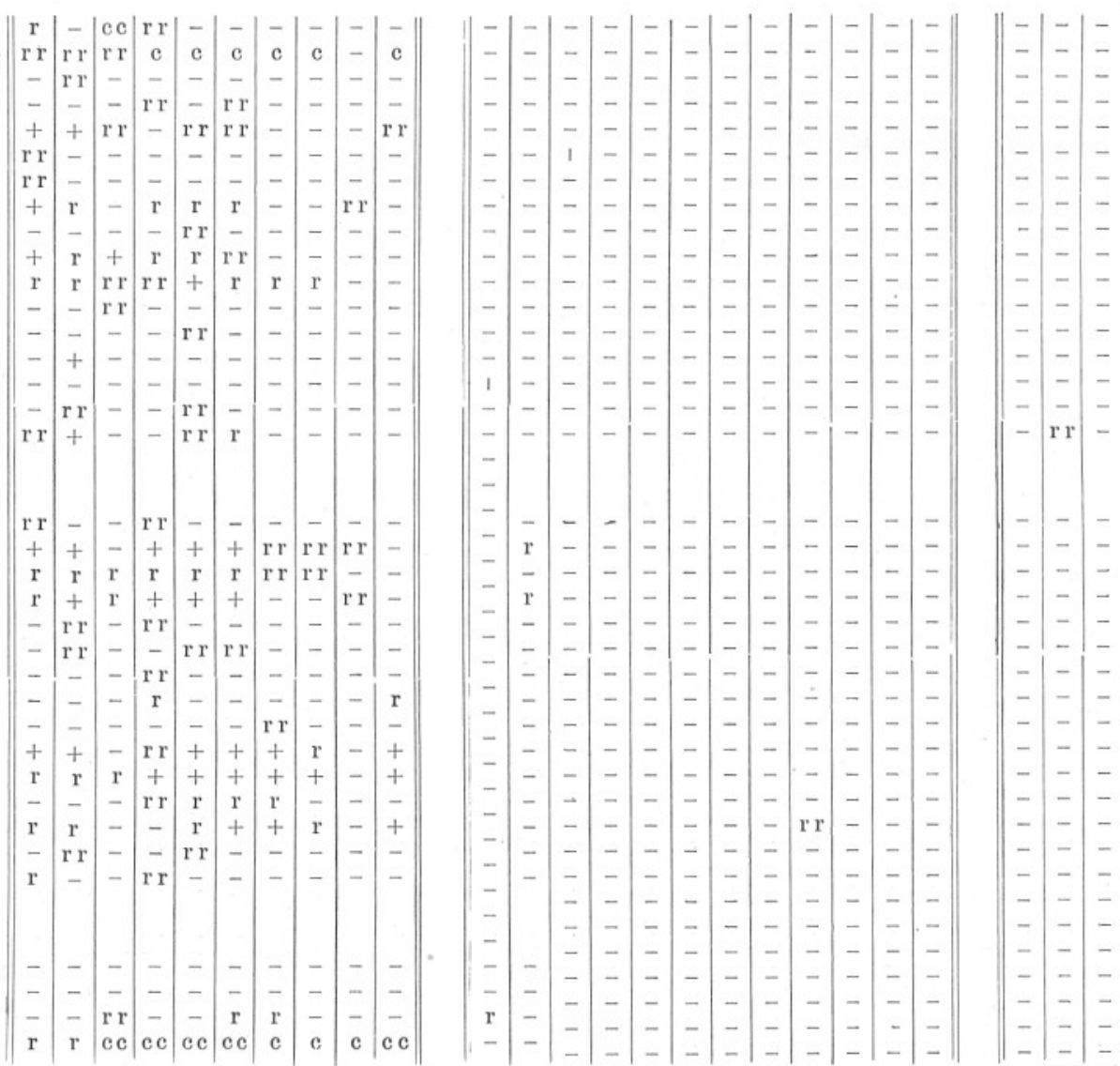
TABLE No. II.-continued.

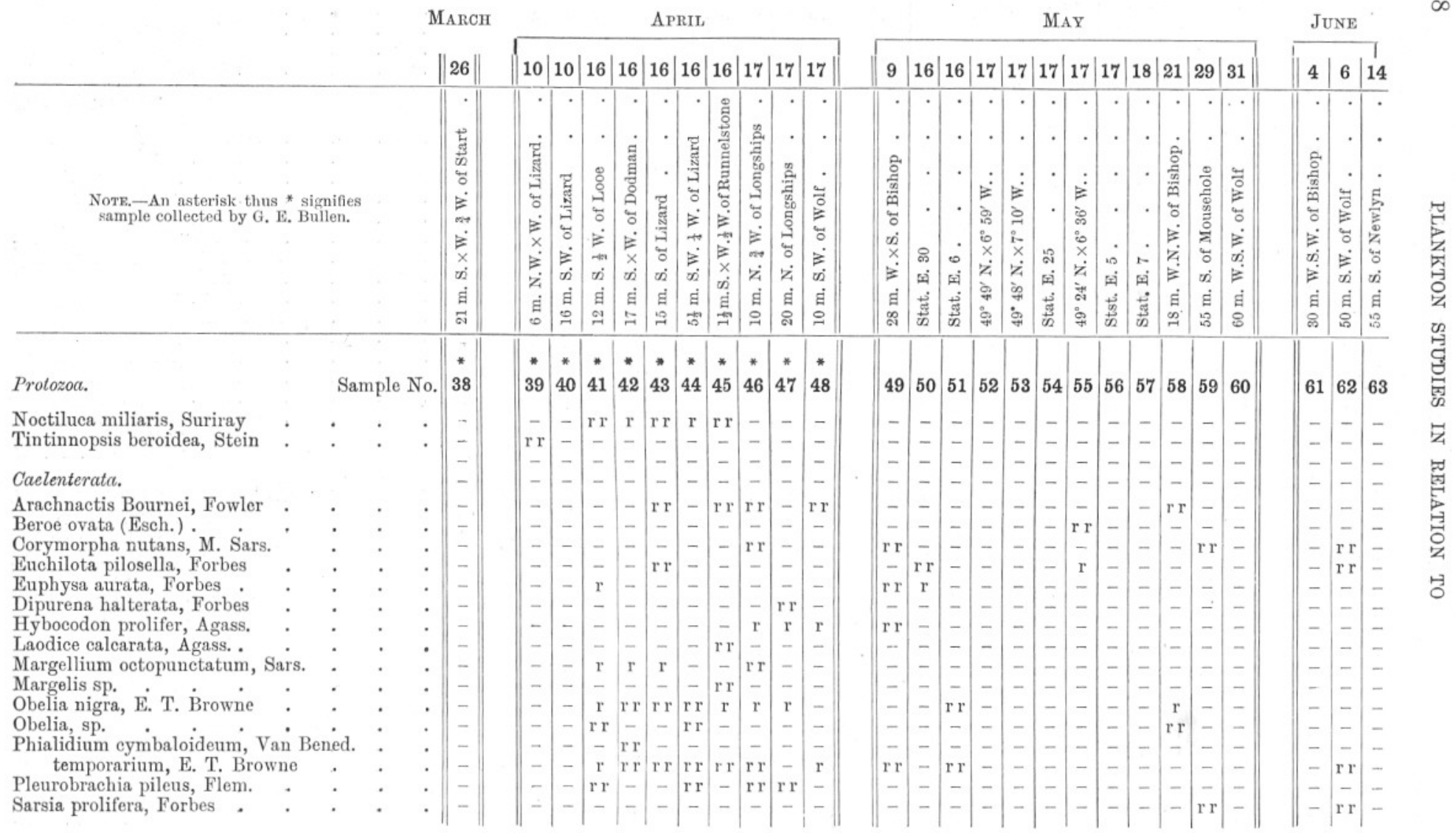


Vermes.

Annelida larvae

Sagitta bipunctata Quoy. and Giaim. Tomopteris helgolandica, Greeff.

Crustacea. Copepoda.

Acartia Clausi, Giesbr.

Anomalocera Pattersoni, Templt.

Calanus finmarchieus, Gunn

Candace pectinata, Brady

Centropages typicus, Krồyer

Corycaeus anglicus, Lubb.

Euterpe acutifrons (Dana)

Isias clavipes, Boeck.

Metridia lucens, Boeck.

Oithona nana, Giesbr.

similis, Claus.

Paracalanus parvus, Claus.

Pseudocalanus elongatus, Boeck.

Temora longicornis, O. F. Mull

Crustacea cetera.

Anchialus acrilis, G. O. Sars. Apherusa Clevei, G. O. Sars. Carididae larvae

Euthemisto gracillipes, Norman

Evadne Nordmanni, Loven

Nauplius .

Nictyphanes Couchii, Bell.

Podon intermedius, Lilljeb.

Zoeae

Zoeae, Megalopa stage

Mollusca.

Gasteropoda larvae

Lamellibranchiata larvae.

Limacina retroversa, Flem.

Tunicata.

Oikopleura dioica, Fol.

Vertebrata.

Fish ova .

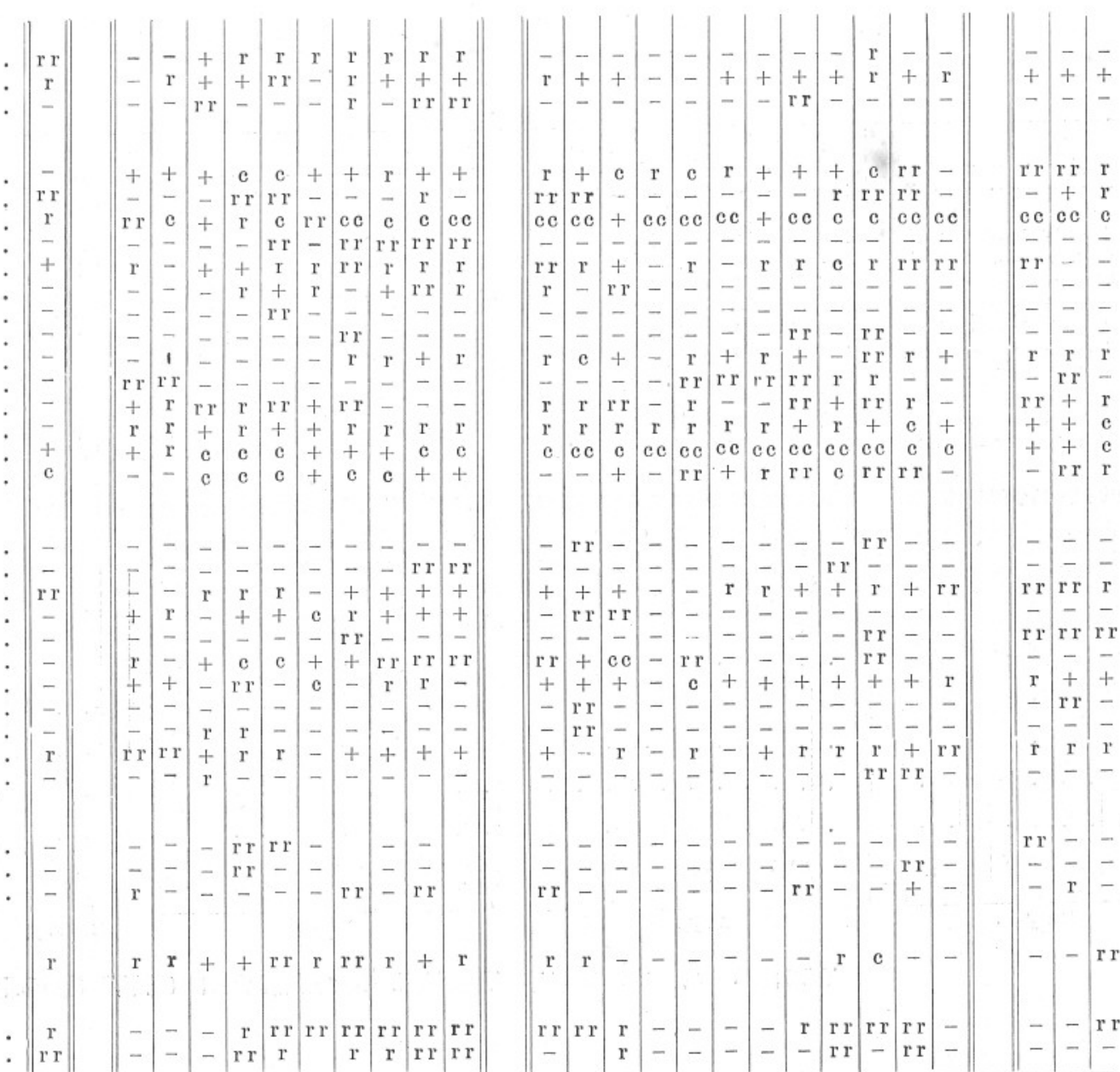

是 
TABLE No. III.-FOOD AND PLANKTON TABLE. Western Area, 1906.

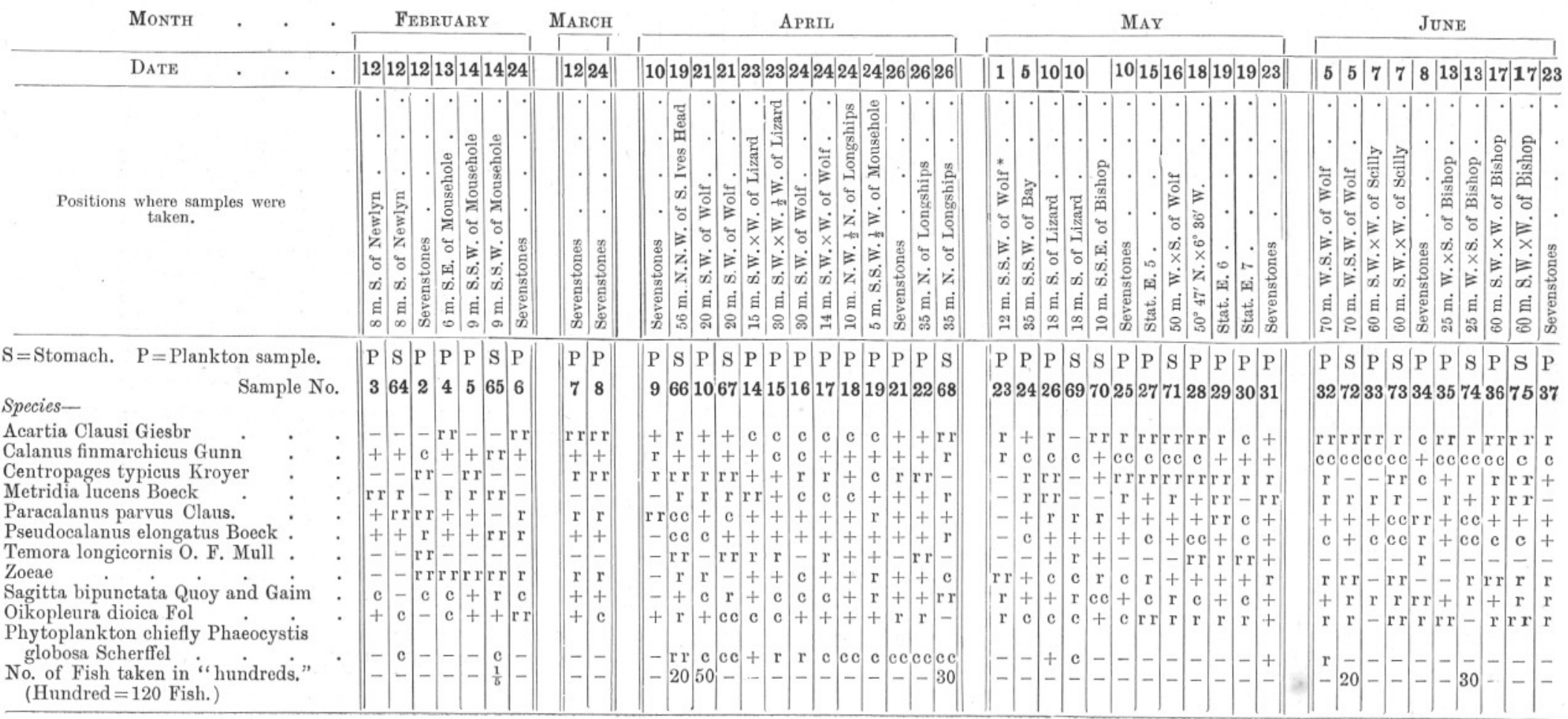




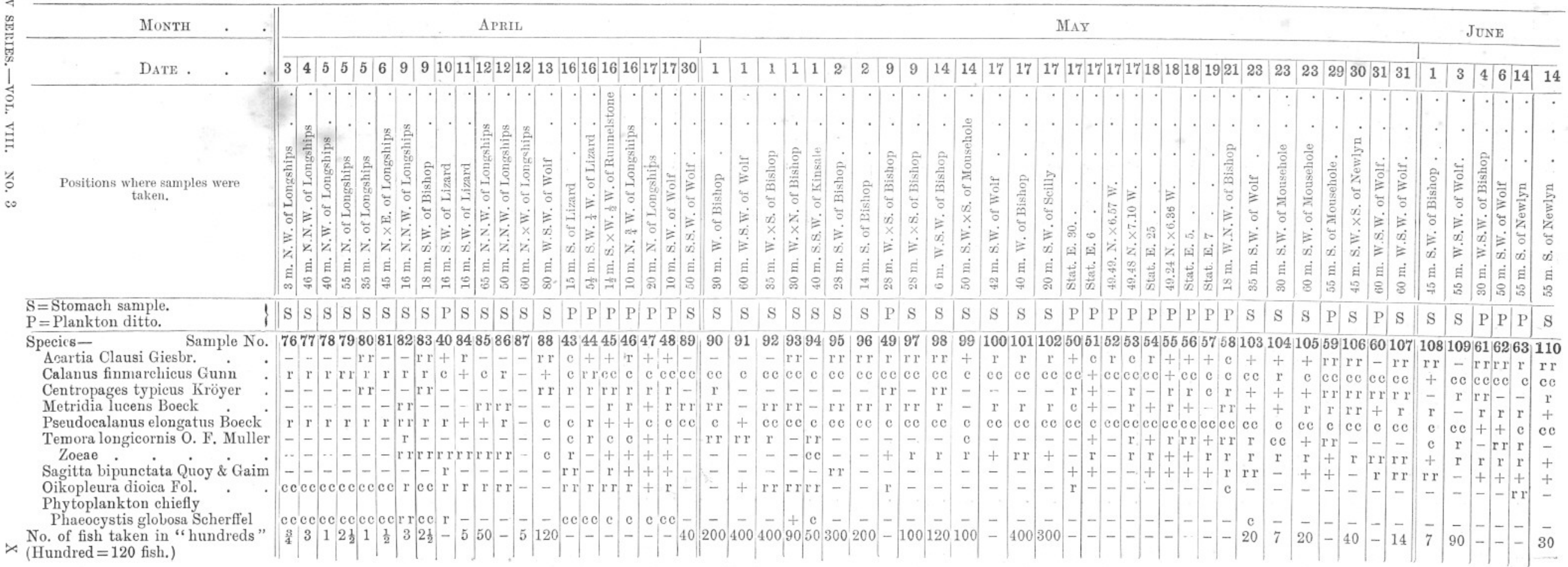


TABle No. V.-FOOD AND PLANKTON TABle. Plymouth to Lizard Area, 1907.

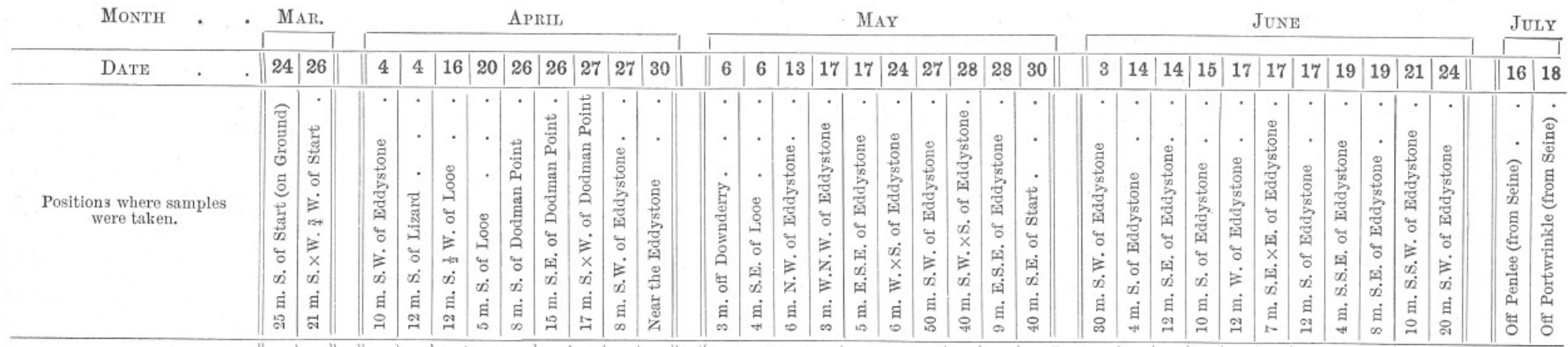

$\mathrm{S}=$ Stomach. $\mathrm{P}=$ Plankton

$\mathrm{S}$

Sample No. . Species.

\begin{tabular}{cc|c}
$\mathrm{S}$ & $\mathrm{P}$ \\
111 & 38
\end{tabular}

Acartia Clausi, Giesbr.

Calanus finmarchicus, Gumn

Pseudocalanus elongatus,

Boeck.
Temora longicornis, O. F.

Mull.

Zoeae.

Sagitta bipunctata, Quoy

Oikopleura dioica, Fol.

Young Fish or Crystallo-

gobius

Phytoplankton, chiefly

Phaeocystis globosa

Scherffel
No. of Mackerel taken in

No. of Mackerel taken in
"hundreds".

(Hundred $=120$ fish)

r r $t$

c c c

$\operatorname{rrr}$

(1) \begin{tabular}{llllllllll|lllllllllll}
$\mathrm{S}$ & $\mathrm{S}$ & $\mathrm{P}$ & $\mathrm{S}$ & $\mathrm{S}$ & $\mathrm{S}$ & $\mathrm{P}$ & $\mathrm{S}$ & $\mathrm{S}$ & & $\mathrm{S}$ & $\mathrm{S}$ & $\mathrm{S}$ & $\mathrm{S}$ & $\mathrm{S}$ & $\mathrm{S}$ & $\mathrm{S}$ & $\mathrm{S}$ & $\mathrm{S}$ & $\mathrm{S}$
\end{tabular}

$11211341 \quad 11411511649117118$

119120121122123124125126127128

$\begin{array}{llllllllllll}\mathrm{S} & \mathrm{S} & \mathrm{S} & \mathrm{S} & \mathrm{S} & \mathrm{S} & \mathrm{S} & \mathrm{S} & \mathrm{S} & \mathrm{S} & \mathrm{S}\end{array}$

$\begin{array}{lllllllllll}129 & 130131 & 132 & 133 & 134 & 135 & 136 & 137 & 138 & 139\end{array}$

$\operatorname{rr}-\quad-\quad+\quad++++\frac{\mathrm{c}}{\mathrm{r}}+\mathrm{r}$

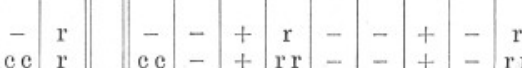

\begin{tabular}{|l|l|c|c|c|c|c|c|c|c|c|}
$\mathrm{ccc}$ & + & $\mathrm{c} \mathrm{c}$ & - & $\mathrm{c} \mathrm{c}$ & + & - & - & $\mathrm{cc}$ & - & $\mathrm{r}$ \\
60 & - & 5 & 5 & - & 10 & 30 & 40 & - & 40 & 7
\end{tabular} $\operatorname{rrr}-\operatorname{rr}--\operatorname{rr}-\operatorname{rrrr}$

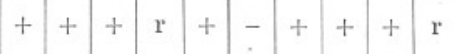

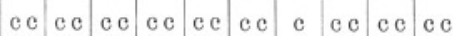

$\mathrm{c}++\mathrm{r} \quad \mathrm{cc} e \mathrm{cc}-+\mathrm{c} r$

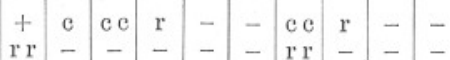

$\operatorname{rrrr}$ e $\quad$ - r e $\quad$ e e + -

$-1010--10-12 \frac{1}{2} 8$ 
Journ. Mar. Biol. Assoc., Vol. YIII.

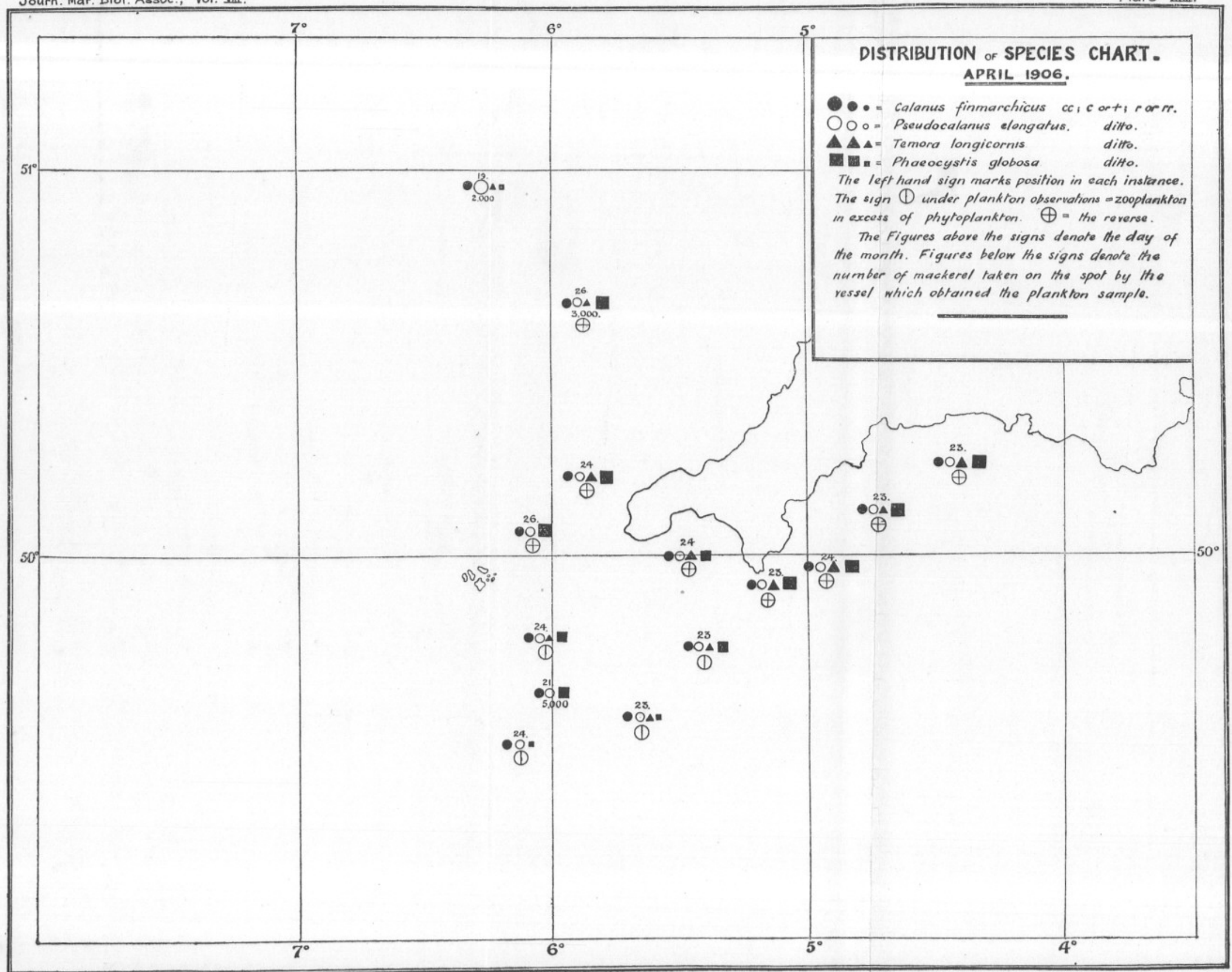

To face $p .302$. 


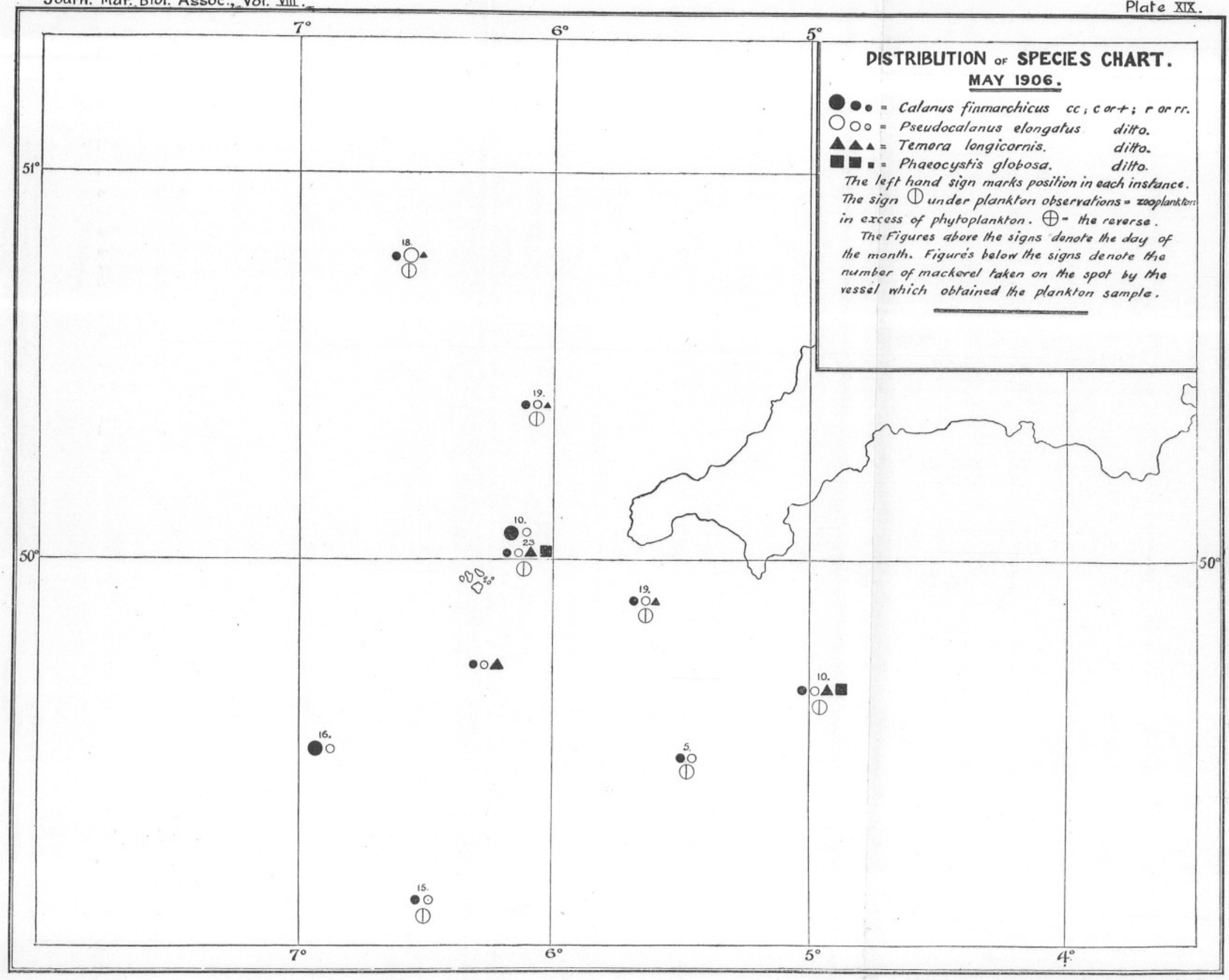


Journ. Mar. Biol. Assoc., Vol. VIII.

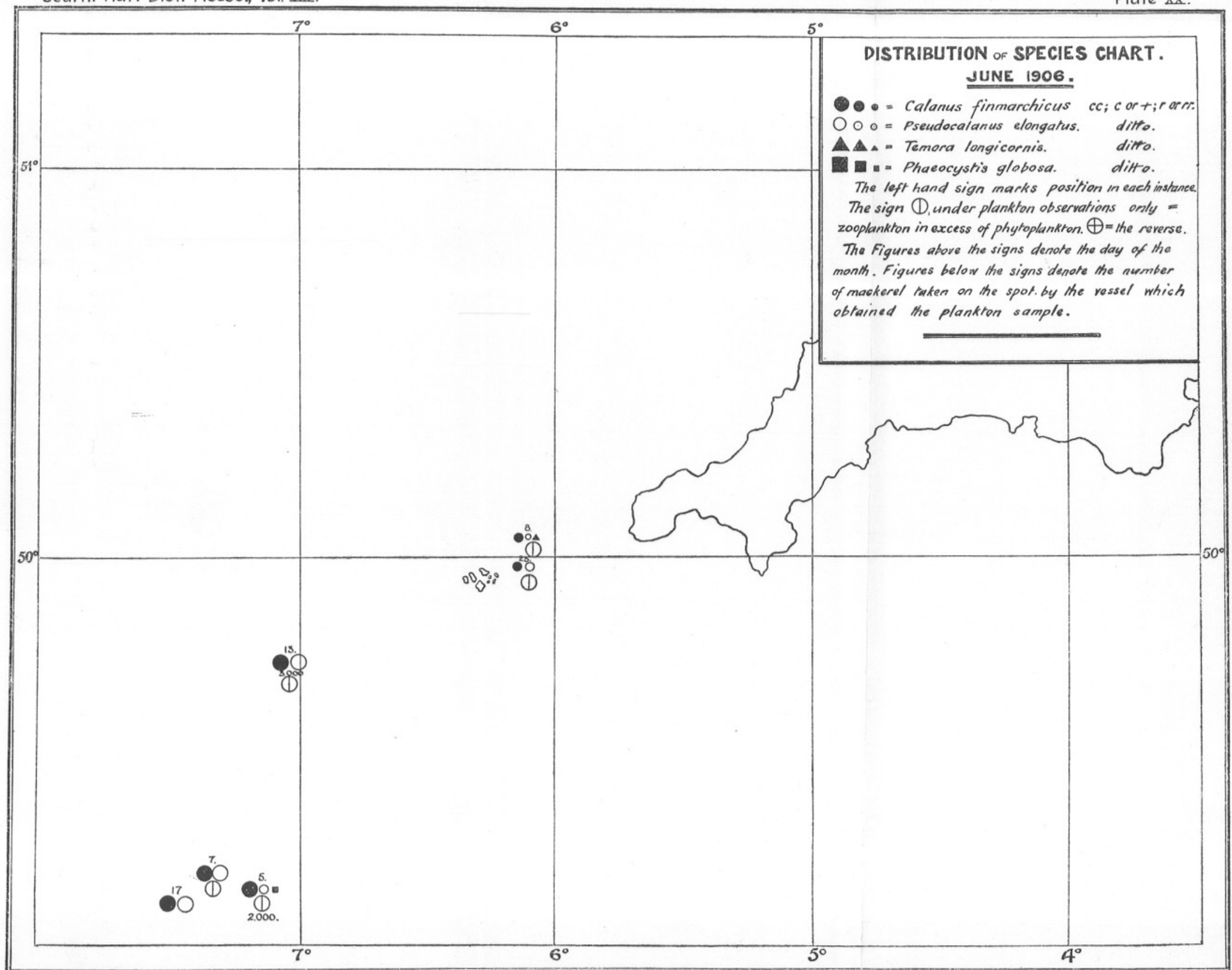




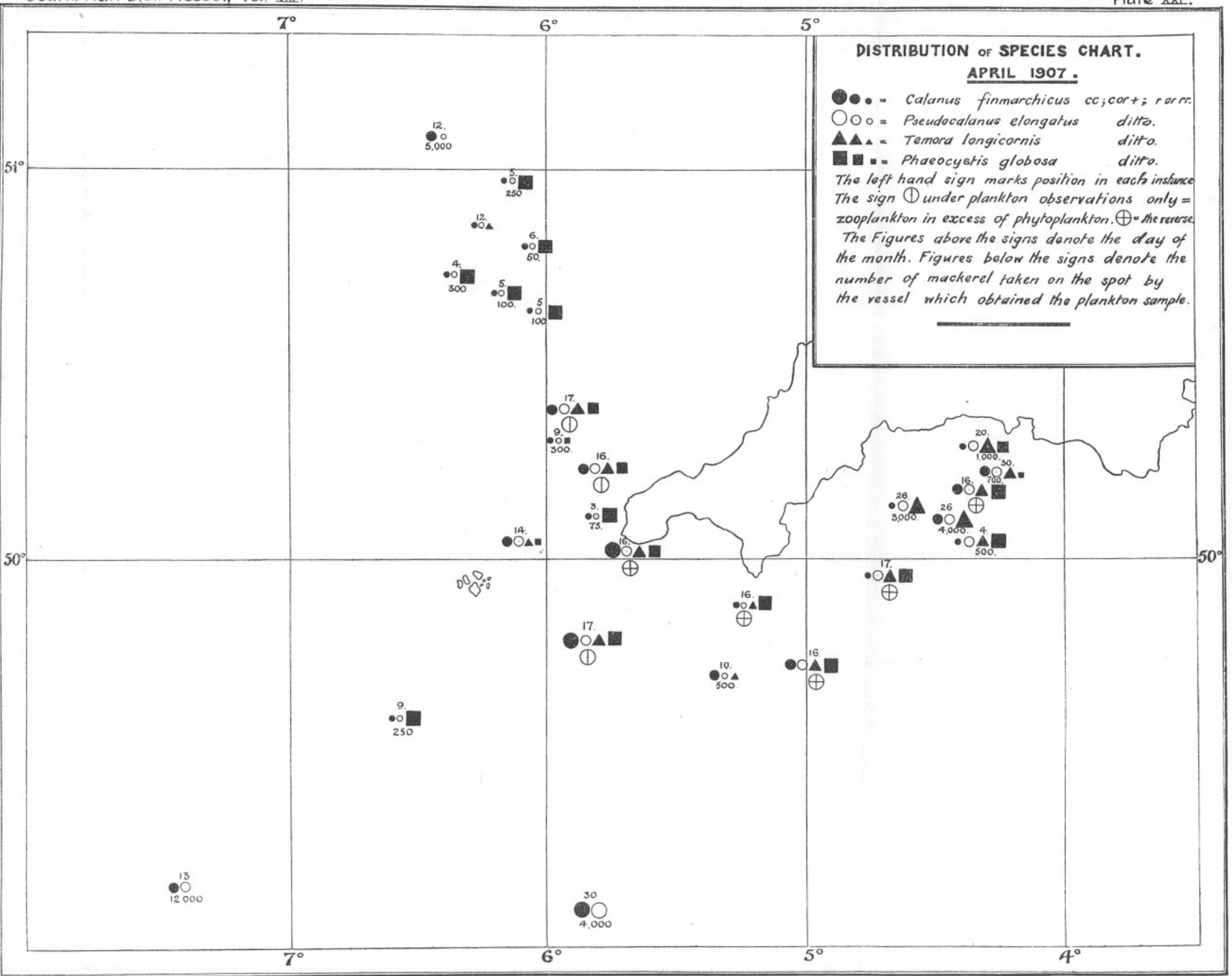




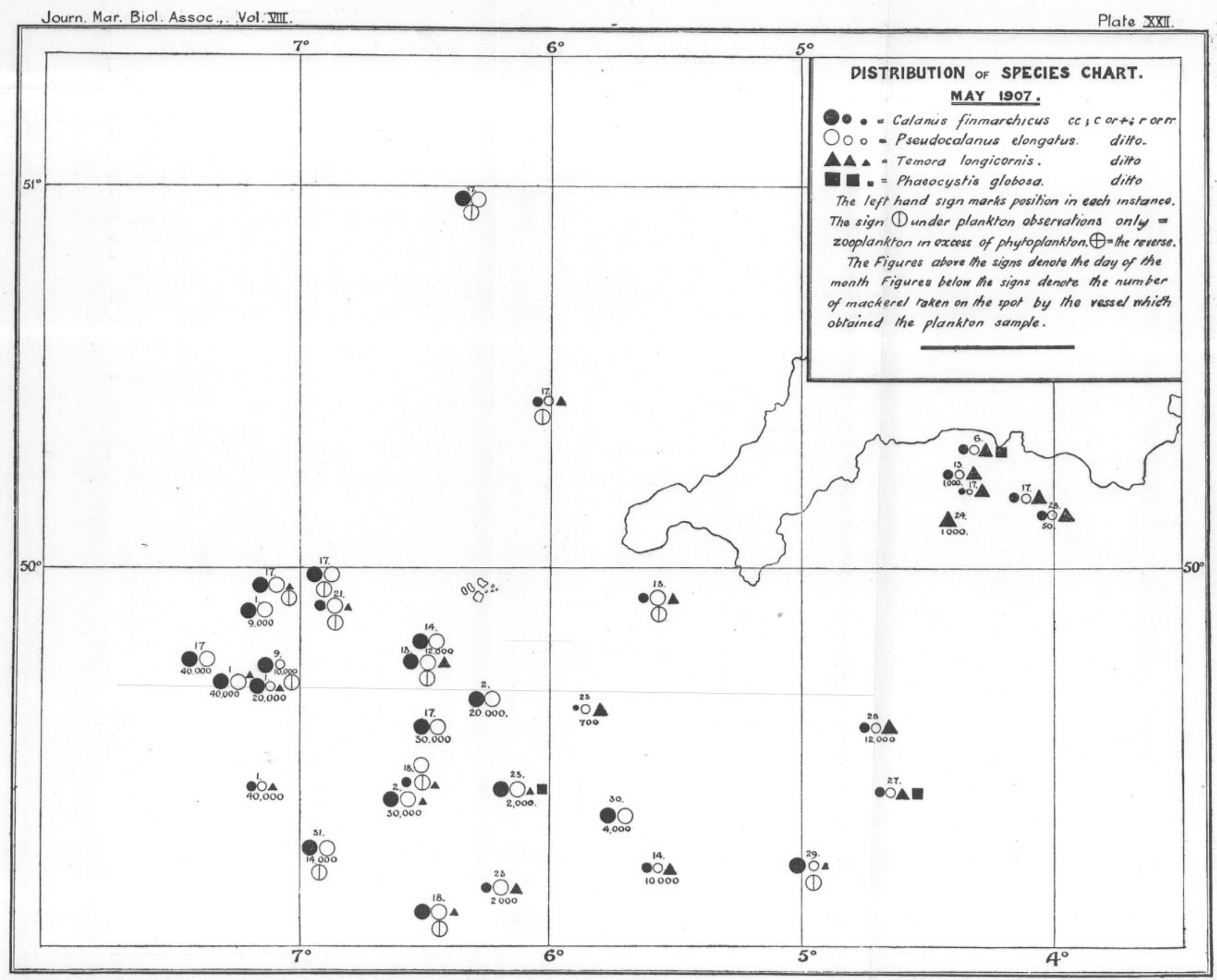


